\title{
Radargrammetric approaches to the flat relief of the amazon coast using COSMO-SkyMed and TerraSAR-X datasets
}

\author{
Ulisses Silva Guimarães ${ }^{\mathrm{a}, \mathrm{c}, *}$, Igor da Silva Narvaes ${ }^{\mathrm{b}}$, Maria de Lourdes Bueno Trindade Galo ${ }^{\mathrm{c}}$, \\ Arnaldo de Queiroz da Silva ${ }^{\mathrm{d}}$, Paulo de Oliveira Camargo ${ }^{\mathrm{c}}$

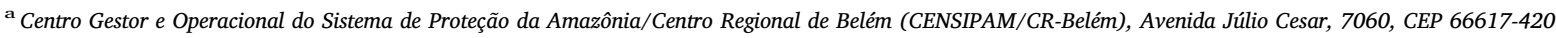 \\ Belém, PA, Brazil \\ b Instituto Nacional de Pesquisas Espaciais/Centro Regional da Amazônia (INPE/CRA), Parque de Ciência e Tecnologia do Guamá, 2651, CEP 66077-830 Belém, PA, \\ Brazil \\ ${ }^{\mathrm{c}}$ Universidade Estadual Paulista (Unesp), Faculdade de Ciências e Tecnologia, Presidente Prudente, Rua Roberto Simonsen, 305, CEP 19060-900 Presidente Prudente, SP, \\ Brazil \\ ` Universidade Federal do Pará/Instituto de Geociências (UFPA/IG), Rua Augusto Corrêa, 01, CEP 66075110 Belém, PA, Brazil
}

\section{A R T I C L E I N F O}

\section{Keywords:}

Synthetic aperture radar

Radargrammetry

Amazon coastal environments

Digital surface models

\begin{abstract}
A B S T R A C T
The Amazonian coast consists of extensive flood plains and plateaus characterized by a high discharge of water and sediment from the Amazon River. This wide landscape occurs under a tropical climate with heavy rains and high cloud cover, making it unsuitable for conventional mapping based on optical images. Additionally, the flat relief and vegetation structure of the Brazilian Amazon coast define an incoherent to partially coherent behavior for the microwave signal, rendering radargrammetric models more suitable for the three-dimensional mapping of its surface. This study aimed to assess the digital surface models (DSMs) provided by Cosmo-SkyMed (CSK) and TerraSAR-X (TSX) Stripmap datasets throughout the radargrammetric models from SARscape and Toutin. The DSMs were generated from SAR (synthetic aperture radar) data with an acquisition geometry that addressed the need for a compromise between the intersection angles and low temporal decorrelation. The radargrammetric SARscape and Toutin's models were developed from different amounts of stereo ground control points (SGCP). The generated DSMs were evaluated considering a set of 40 independent checkpoints (ICP) measured by GNSS in the field, in their entirety and disaggregated by coastal environment. The vertical accuracy was based on the estimation of the discrepancies, bias and precision (standard deviation and root mean square error RMSE), and the Taylor and Target diagrams were used for a more comprehensive comparison. In the vertical accuracy analysis using all ICPs measured in situ, the DSM obtained by the SARscape's model from the CSK SAR data resulted in the lowest RMSE $(4.34 \mathrm{~m})$ and mean discrepancy $(0.05 \mathrm{~m})$, but Toutin's model had the lowest standard deviation $(2.58 \mathrm{~m})$ of the discrepancies. The Taylor and Target diagrams showed fluctuations in accuracy that alternated the DSMs generated from the two types of SAR data, indicating that TSX produced more stable models and CSK produced better vertical accuracy. The Amazon Coastal Plateau and Fluvial Marine Terrace environments defined three-dimensional representations with lower RMSEs (better than 7.8 and 8.9 m, respectively), regardless of the type of SAR data or the radargrammetric model used. The worst performance, which was for the Fluvial Marine Plain, was influenced by the specific characteristics of this coastal environment, such as the structure of the mangrove vegetation and the shoreline. In general, the high resolution and good ability to revisit the SAR data used, together with the radargrammetric models, allowed for the accurate mapping of the flat relief of the Amazon coastal environments, providing detailed spatial information that can be acquired in severe rainfall conditions in a region of intense morphological dynamics.
\end{abstract}

\section{Introduction}

The Amazon River is the major contributor of freshwater and sediment on the Amazon coast, which creates a unique coastal environment constituted by a delta and an estuary (Silveira, 1964; Meade et al., 1985; Nittrouer et al., 1986; Tessler and Goya, 2005). This coastal

\footnotetext{
* Corresponding author.

E-mail addresses: ulisses.silva@sipam.gov.br (U.S. Guimarães), igor.narvaes@inpe.br (I.d.S. Narvaes), mlourdes@fct.unesp.br (M.d.L.B.T. Galo), arnaldoq@ufpa.br (A.d.Q. da Silva), paulo@fct.unesp.br (P.d.O.Camargo).
} 
segment is characterized by humid tropical conditions of high precipitation, dominated by semidiurnal macrotidal conditions, and constitutes the second largest sedimentary contribution in the world. The conditions of this wide continental shelf promote the formation of extensive, periodically flooded plains and lowered plateaus between 10 and $70 \mathrm{~m}$ supported by older sedimentary rocks (Costa et al., 1996; Geyer et al., 1996; El-Robrini et al., 2006). In the Brazilian territory, the Amazon coast spans approximately $1200 \mathrm{~km}$ in a straight line, with an estimated population of 5.11 million people; this area has been exposed to intense morphological changes that, in the last decade, resulted in a sediment deposition rate of $160.92 \mathrm{~km}^{2} \cdot \mathrm{yr}^{-1}$ and a $101.04 \mathrm{~km}^{2} \cdot \mathrm{yr}^{-1}$ erosion rate (Zamboni and Nicolodi, 2008; Nascimento et al., 2013). These physical and environmental conditions require systematic monitoring using updated cartography on regional and local scales.

The systematic mapping of humid tropical coastal environments demands the production of primary data such as digital surface models (DSMs) obtained from synthetic aperture radar (SAR) systems. The systems that utilize microwaves consider the electrogeometric properties of the targets and present few restrictions on the atmospheric conditions and controlled acquisition geometry. In the mapping process, an accurate DSM can be a reliable data source of ground information applicable for the topography, identification of geological or geomorphological substrates, hydrology, susceptibility to erosion, flooding and so on.

The main techniques to generate DSM from an SAR dataset are interferometry and radargrammetry (Bamler, 2000; Crosetto and Pérez, 2000; Toutin and Gray, 2000). Radargrammetry allows the extraction of geometry information from the amplitude SAR images (Leberl, 1990) using the same approach that photogrammetry uses for optical images. Since the radargrammetric DSMs are generated from the amplitude and it is usually necessary to resample this information to minimize the speckle, there is a loss of precision in comparison with the interferometry that is based on the phase under a single look (Woodhouse, 2006). However, the stereoscopic pairs of SAR systems are more suitable for the three-dimensional reconstruction of incoherent or partially coherent targets due to the temporal decorrelation between interferometric acquisitions, specifically over coastal wet zones under high cloudiness and dense forest cover (Méric et al., 2009; Wang, 2010). In short, the radargrammetric approach is less influenced by vegetation structure, atmospheric conditions and the dielectric properties of targets. The theoretical performance of the radargrammetric method, in terms of positional accuracy, is influenced by the radiometric correspondence of the stereo pairs and the incidence angle (Toutin, 2004; Fayard et al., 2007). The vertical accuracy depends on the number of stereo ground control points (SGCP) used in the DSM construction.

Currently, the SAR systems have achieved a new level to generate DSMs due to increased spatial resolution, short revisit time and a wide variety of incidence angles (Paradella et al., 2012; Ouchi, 2013). These issues have been investigated in several recent contributions. Toutin and Chenier (2009) used Radarsat-1 ultrafine datasets from urban/ semi-rural areas and temperate forests and achieved a vertical accuracy of $2.2 \mathrm{~m}$. Raggam et al. (2010) applied a multibeam approach to TerraSAR-X Spotlight mode on slightly hilly rural areas and temperate forests and reached a vertical accuracy of $2 \mathrm{~m}$. Oliveira et al. (2011) used the TerraSAR-X Stripmap dataset to model tropical forest and mountainous relief and obtained a vertical accuracy of $6.7 \mathrm{~m}$. Capaldo et al., (2015) applied different radargrammetry approaches to SAR Spotlight datasets from a temperate coastal area with hilly relief and attained a vertical accuracy of $5 \mathrm{~m}$. Salvini et al. (2015) used CosmoSkyMed Stripmap datasets from desert areas and achieved a relative vertical error of $11.8 \mathrm{~m}$. In addition, there have been initiatives to improve the radargrammetric models (Toutin, 2004; Balz et al., 2009; Perko et al., 2011; Capaldo, 2013; Gutjahr et al., 2014; Yu et al., 2014) and to solve the major source of error provided by relief and landscape (Toutin, 2000, 2002; Soergel et al., 2009; Zeger and Avent, 2013; Koyama et al., 2016; O’Loughlin et al., 2016).
Elaborating three-dimensional reconstruction models of the Amazon coast, with its flat relief and dynamic landscape, that have adequate precision for the topographic mapping and morphological monitoring of the coastal environments is challenging. The main goal of this paper is to evaluate the vertical accuracy of DSMs under Amazon coastal environments generated from Cosmo-SkyMed (CSK) and TerraSAR-X (TSX) Stripmap datasets, using both Toutin's and SARscape's radargrammetric models.

\section{Study area and SAR datasets}

The Amazon River mouth is a unique coastal environment classified as a delta and an estuary, as a result of the geological genesis of a drowned valley, with a hydrological flow of $6.3 \times 10^{12} \mathrm{~m}^{3} \cdot \mathrm{yr}^{-1}$ and discharge of sediments of $1.2 \times 10^{9}$ ton $\mathrm{yr}^{-1}$ contributing to the sedimentation of the continental shelf at a rate of $10 \mathrm{~cm} \cdot \mathrm{yr}^{-1}$ (Nittrouer et al., 1986, 1995). The hydrodynamics are responsible for the ebb and flow of semidiurnal meso to macrotidal action, which varies from 3 to $5 \mathrm{~m}$. During high tide, the currents reach approximately 2.1-1.9 knots, with waves whose height varies from 0.3 to $1.5 \mathrm{~m}$ and a coastal shunt preferentially in the SE-NW direction, as defined by the coastal shoreline (El-Robrini et al., 2006; Zamboni and Nicolodi, 2008). This dynamic of the Amazon coast provides erosional and accretional morphological features along the shoreline, reinforcing the need for continuous monitoring of the region. The weather is warm, wet and tropical, with a strong influence of the Intertropical Convergence Zone (ICZ), defining a rainy season from December to May, with an average precipitation of $3000 \mathrm{~mm}$ and average wind speeds of $6.2 \mathrm{~m} \cdot \mathrm{s}^{-1}$. The dry season occurs from June to November with an average precipitation of $350 \mathrm{~mm}$ and an average wind speed of $7 \mathrm{~m} \cdot \mathrm{s}^{-1}$ (Martorano, 1993).

A geomorphological map produced in 2004 by IBGE (2015) indicates the occurrence of three environmental units on a regional spatial scale, which is the focus of this study. The Coastal Plateau (CP) is an extensive and dissected compact relief, supported mainly by layers of sandstones and mudstones at elevations above $5 \mathrm{~m}$ on the upland, whose land cover is composed of bare soil, artificial structures and dense forests (Costa et al., 1996). The Fluvial Marine Plain (FMP) has curvilinear forms of continental portions and extensive areas in the coastal region, characterized by clayey and sandy layers with the fluviomarine origin. This wetland has mangroves as the predominant land cover but also with shrub vegetation over the sandbars occurring in ancient and recent shores. The Fluvial Marine Terraces (FMT) are flat areas formed by the accumulation of sediments transported by the oscillation of tides, rivers and lakes. Its land cover consists of large fields with grassland and shrubs (França and Souza Filho, 2006), at a topographic level above the FMP.

The study area is $30 \times 20 \mathrm{~km}$, defined by the intersection of stereoscopic pairs obtained from both CSK and TSX platforms during the rainy season. The area covers the eastern border of Marajó Island, located in the southern mouth of the delta and estuary complex (Fig. 1).

The SAR images were acquired by CSK 2 and 3 and TSX 1: operating in X-band (wavelength of $3.1 \mathrm{~cm}$ ), descending orbit, right look in azimuth direction $\pm 281^{\circ}$ (WNW), Stripmap mode (SM), single look complex (SLC), internal radiometric calibration with full metadata contained, and horizontal polarization at emission and reception (HH). The CSK $2 / 3$ and TSX 1 dataset were provided through the scientific proposal, submitted to the Italian Space Agency (ASI) and German Aerospace Centre (DLR), project identifications are 201 and COA2686, respectively.

Scenes acquired under similar physical conditions are a premise for mapping coastal environments, since such conditions affect spatial and temporal scales (Wang, 2010). Thus, the selection of SAR images was based on criteria such as availability, incidence angle between $24^{\circ}$ and $51^{\circ}$ and temporal decorrelation at a maximum of 5 days. These characteristics, in addition to climatic conditions, tidal and lunar cycles (DHN, 2016; INMET, 2016), recorded at the acquisition date of each 
b)

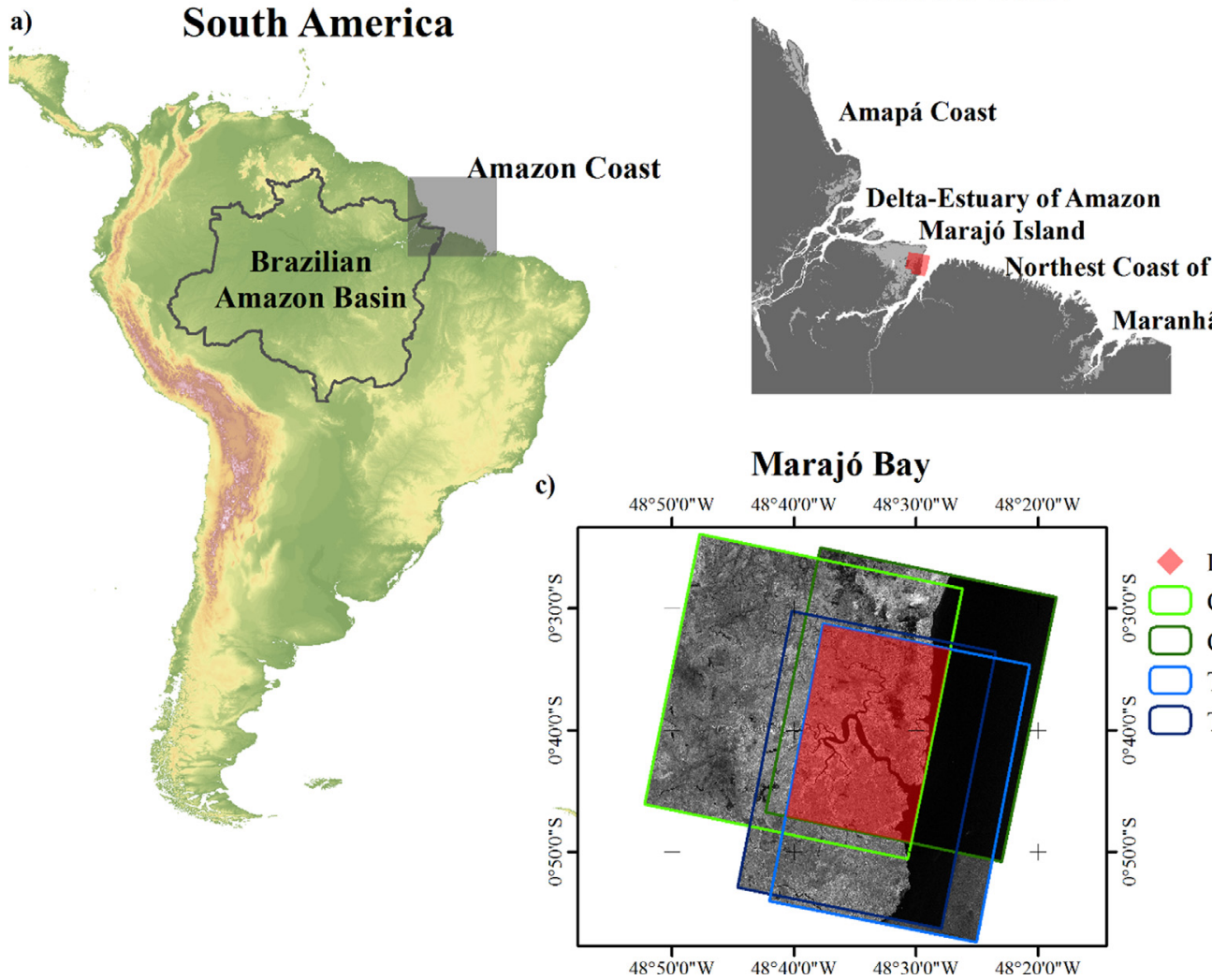

Amazon Coast<smiles>C1CN1</smiles>

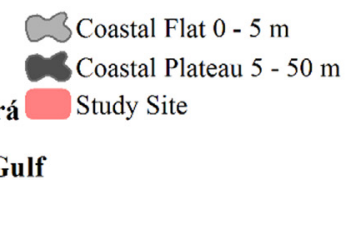

Intersection Area

CSK 2: $29.09^{\circ}$ from 07-Apr-2016

CSK 3: $45.21^{\circ}$ from 02-Apr-2016

TSX 1: $23.95^{\circ}$ from $30-M a r-2016$

TSX 1: $44.46^{\circ}$ from 25-Mar-2016

Geographic Coordinate System Lat/Long

Reference System

WGS-84

Fig. 1. (a) Amazon coast and basin located in Brazilian territory; (b) compartments of Amazon coast and basic geomorphological units: Coastal Plateau and Coastal Flat; (c) study area defined by the intersection of stereoscopic pairs obtained from CSK and TSX systems during the rainy season and under variable incidence angles $(\theta)$.

Table 1

SAR scene characteristics and weather conditions, tide and lunar cycles, corresponding to the acquisition date of each scene.

\begin{tabular}{|c|c|c|c|c|}
\hline SAR Dataset & $\operatorname{CSK} 3^{1}$ & $\operatorname{CSK} 2^{1}$ & $\operatorname{TSX} 1^{2}$ & \\
\hline Mode/Product/Level & \multicolumn{2}{|c|}{ SM/HIMAGE/SLC } & \multicolumn{2}{|l|}{ SM/SLC } \\
\hline Orbit/Look Direction & \multicolumn{2}{|c|}{ Descending/Right } & \multicolumn{2}{|c|}{ Descending/Right } \\
\hline Incidence Angle $\left({ }^{\circ}\right)$ & $50.3-52.0$ & $30.7-33.7$ & $43.4-45.5$ & $22.3-25.6$ \\
\hline Spatial Resolution (m) & $2.7 \times 2.8$ & $2.3 \times 2.8$ & $3.3 \times 2.5$ & $3.3 \times 2.9 \mathrm{~m}$ \\
\hline Swath $(\mathrm{km})$ & $40.9 \times 36.7$ & $41.7 \times 40.9$ & $42.6 \times 31.6$ & $42.7 \times 32.1$ \\
\hline Acquisition Date & 02-Apr-2016 & 07-Apr-2016 & 25-Mar-2016 & 30-Mar-2016 \\
\hline Local Time & $17: 36$ & $17: 48$ & $05: 58$ & $06: 06$ \\
\hline Rain $(\mathrm{mm} / \mathrm{h})^{3}$ & 2.8 & 0.0 & 0.0 & 9.0 \\
\hline 5-Day Rain $(\mathrm{mm} / \text { day })^{4}$ & 60.8 & 9.8 & 20.3 & 42.7 \\
\hline Temperature $\left({ }^{\circ} \mathrm{C}\right)$ & 24.8 & 26.4 & 28.0 & 27.1 \\
\hline Wind $\left(\mathrm{m} \cdot \mathrm{s}^{-1}\right)$ & 1.1 & 1.2 & 2.2 & 1.5 \\
\hline Tide $(\mathrm{m})$ & 3.01 & 0.17 & 0.48 & 1.51 \\
\hline Moon (\%) & 28.5 & 0.0 & 97.2 & 63.7 \\
\hline
\end{tabular}

Source:

1 (C)ASI (2016).

2 CDLR (2016).

3 Rain (mm/h): accumulated rain during the SAR acquisition.

4 5-Day Rain (mm/day): The average of accumulated rain during five days before the SAR acquisition.

CSK and TSX scene are shown in Table 1.

The ground information was acquired by a global navigation satellite system (GNSS), operating in double frequency and static and kinematic modes. Two field campaigns were carried out between 8-12 October 2015 and 12-16 October 2016 to obtain 165 measurements throughout the post-processing technique. For the survey, the 26 bases of 4-h reception, 110 statistic measurements of 30-min reception, and
55 kinematic measurements of 15-s reception were collected in open areas, using $10^{\circ}$ for the elevation mask. The post-processed GNSS data used the GPS and GLONASS constellations with precise orbits, which were fixed in three stations of the Brazilian Geodetic System, located on municipalities of Belém, Santarém and Marabá. The datum WGS-84 was used as a reference system and the orthometric heights were based on MAPGEO2015 geoid model.

From the GNSS dataset collected in the field, a maximum of 12 points were used as stereo ground control points (SGCP) to solve the collinearity equations of the radargrammetric models and were randomly selected at 40 independent checkpoints (ICPs) for DSM quality analysis, provided by GNSS that had a horizontal precision of better than $5.5 \mathrm{~cm}$ and a vertical precision of better than $10.9 \mathrm{~cm}$. The SGCP and ICP surveyed over the Amazon coastal environments are presented in Fig. 2.

\section{Methods}

In evaluating the performance of different types of SAR datasets in the DSM generation by different radargrammetric approaches, the characteristics of the datasets and radargrammetric models used, as well as the particularities of the Amazon environments were considered. The development of the research, outlined in Fig. 3 consisted of (i) the definition of the acquisition geometry of each SAR dataset for the study area; (ii) the accomplishment of a SAR processing chain to obtain the radargrammetry models, according to Fayard et al. (2007), Méric et al. (2009) and Toutin and Chenier (2009); and (iii) statistical analysis to assess the DSM vertical accuracy, based on Galo and Camargo (1994), Taylor (2001), Congalton and Green (2009) and Jolliff et al. (2009). 

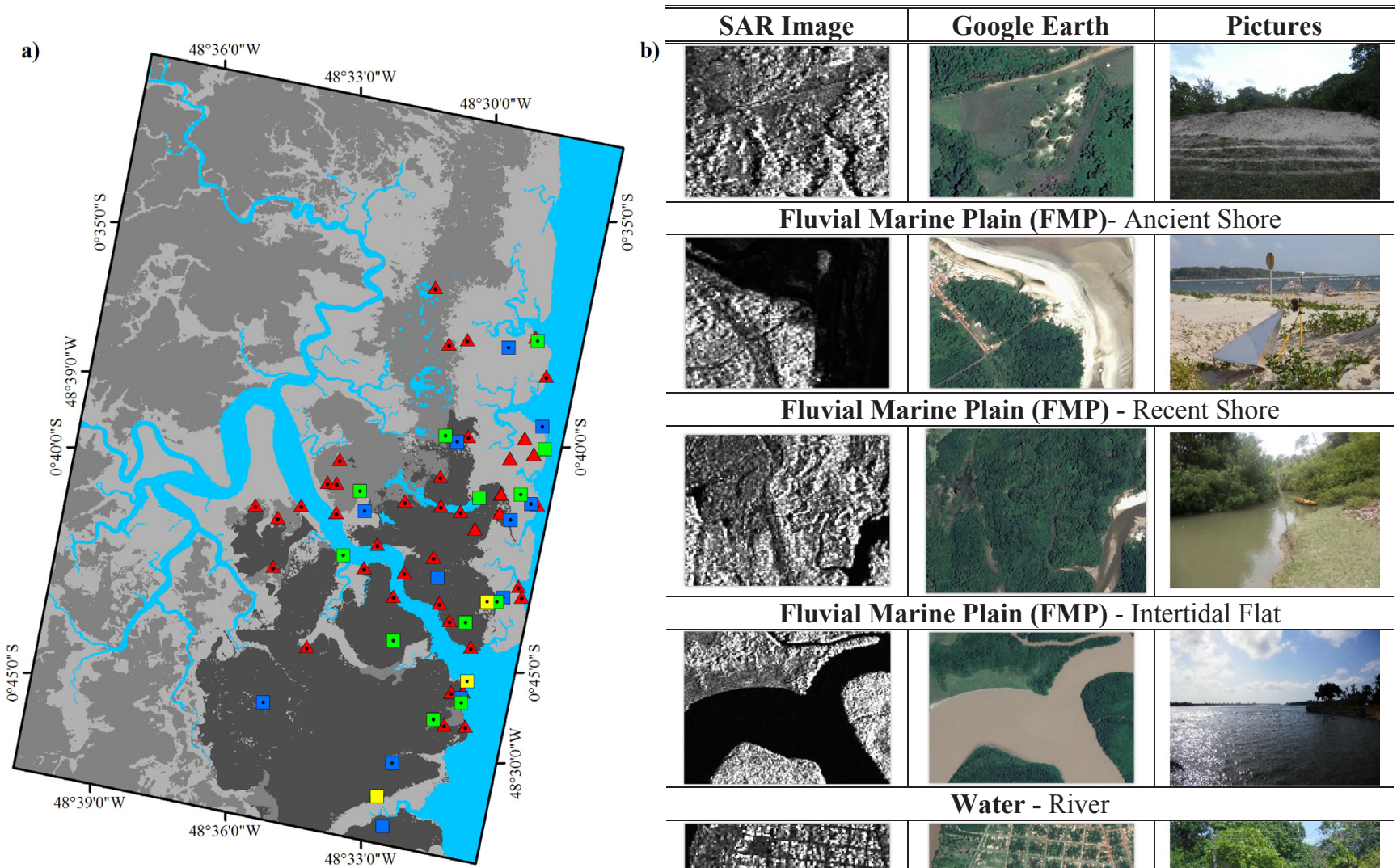

Fluvial Marine Plain (FMP) - Recent Shore

\section{GNSS Data}
- Common SGCP Static
$\square$ Common SGCP Kinematic
- CSK SGCP Static
$\square \quad$ CSK SGCP Kinematic
- TSX SGCP Static
- TSX SGCP Kinematic
$\triangle$ ICP Static
- ICP Kinematic

Amazon Coastal Environments

Coastal Plateau

Fluvial Marine Plain
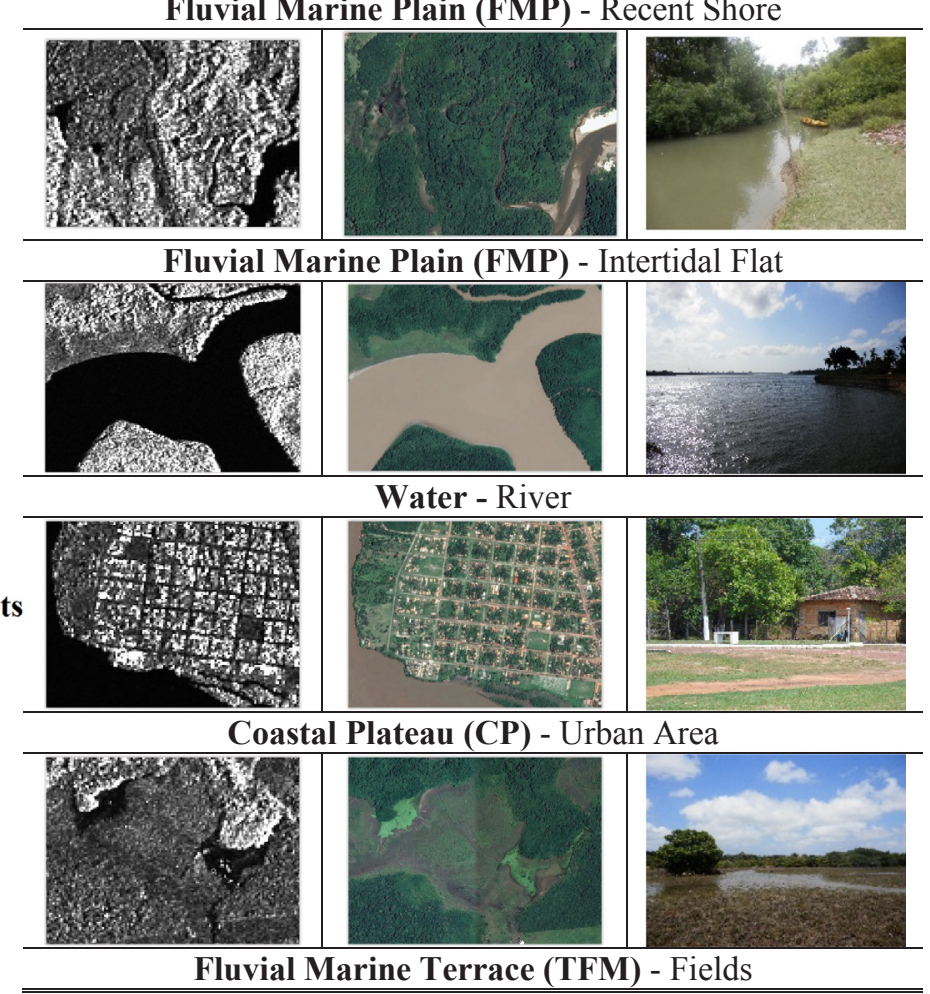

Fig. 2. (a) Spatial distribution of GNSS measurements, specified by type of survey and use in the radargrammetric process. (b) Representation of the Amazon Coastal Environments in the SAR image, Google Earth optical image cropping and field pictures.

\subsection{SAR acquisition geometry for radargrammetry}

Regardless of the incidence angle or path orientation, the acquisition of the SAR radargrammetric pairs considers that the intersection angle between the images is the highest possible to ensure high vertical resolution and, consequently, to maximize the stereoscopic parallax. Simultaneously, the cross-correlation in amplitude should be high enough to ensure the radiometric similarity between the images of the stereo model (Toutin and Gray, 2000; Méric et al., 2009). The main parameters of the SAR acquisitions are indicated in Table 2.

The SAR acquisition geometry for radargrammetry, shown in Fig. 4 for the CSK $2 / 3$ and TSX 1 , considers as a priority (i) stereoscopic parallax, related to the change in target observed from different positions (Polidori, 1997), and (ii) the intersection angle $(\Delta \theta)$ formed by the line-of-sight of observation platforms and with a close relationship with the perpendicular baseline $B_{\perp}$ (Bamler, 2000; Toutin, 2002). To ensure a consistent radargrammetric model, the radiometric cross-correlation at amplitude should be greater than 0.3 , and the height and perpendicular baseline ratio of platforms $\left(B_{\perp} / H\right)$ must vary between 0.25 and 2 or $\Delta \boldsymbol{\theta}>7^{\circ}$ (Méric et al. 2009; He et al., 2010)

\subsection{Radargrammetric models}

Radargrammetry is an approach based on the geometric principles of photogrammetry, in which the construction of stereoscopic models establishes relations between the homologous coordinate measurements of the stereo pairs and the terrestrial surface. Therefore, geometric adjustments are necessary, relating topographic distortions and the intersection of circular concentric beams that are projected on a slant range by Doppler cone (Polidori, 1997). The radargrammetric models assume radar parameters (wavelength, antenna, incidence angle, etc.), state vectors (position, velocity and attitude) and terrestrial reference systems (ellipsoid, geoid and projection) (Méric et al., 2009). Some models were derived from Range-Doppler classical equations (Leberl, 1990) or physical constraints (Toutin, 2004).

In the last decade, the radargrammetric models began to consider the physical and geometric processes of image acquisition by means of more rigorous mathematical modeling or polynomial functions provided by the SAR systems (Toutin and Chenier, 2009), improvements on search windows based on normalized cross-correlation (Fayard et al. 2007; He et al., 2010) and rigorous procedures of orientation and matching (Raggam et al., 2010; Capaldo et al., 2011, 2015). 


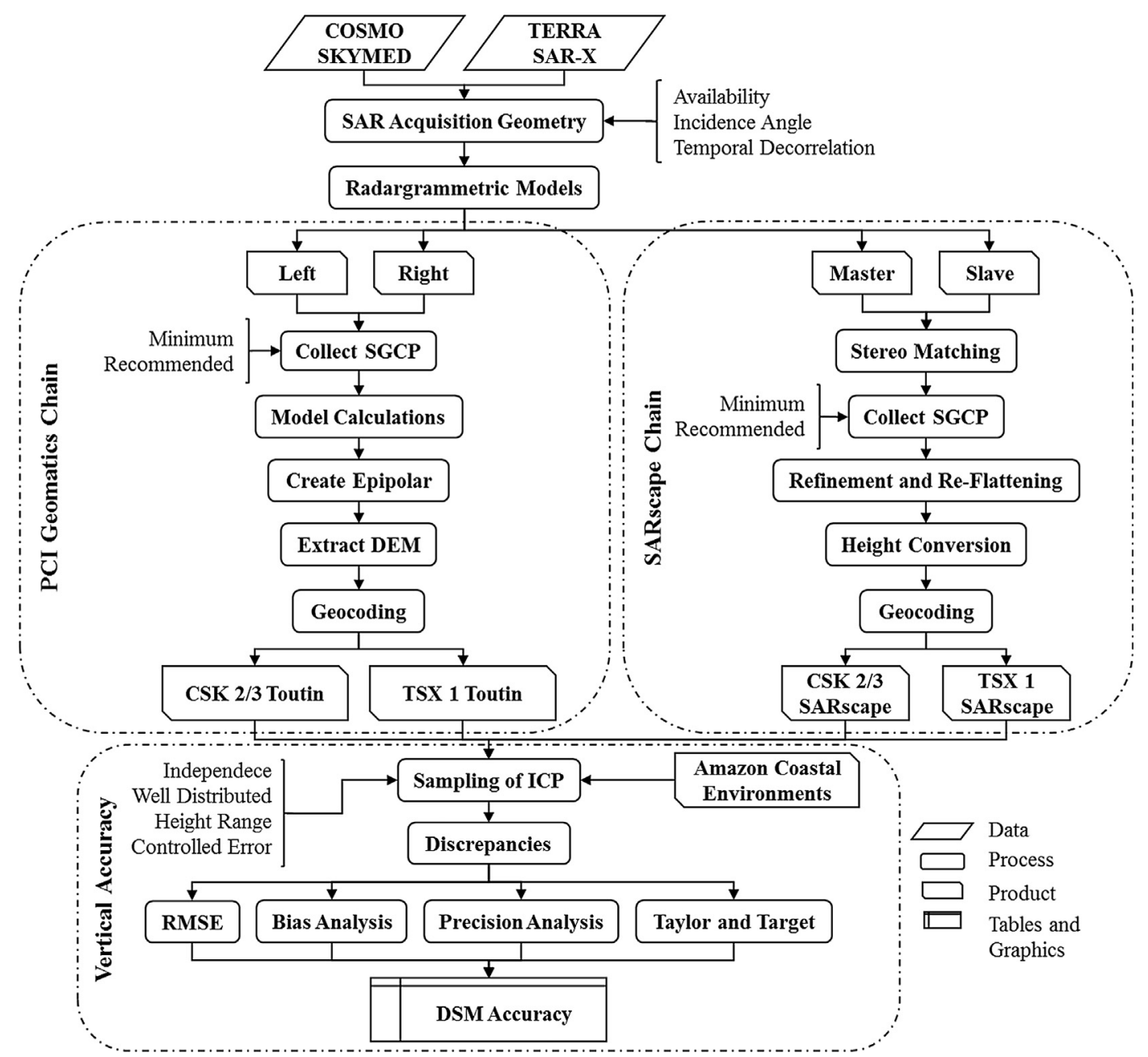

Fig. 3. Overall flowchart of the methodology highlighting the SAR processing chain of the radargrammetric approaches applied to the CSK and TSX datasets and the analysis of the DSMs vertical accuracy.

Table 2

SAR acquisition parameters that influence CSK and TSX data stereoscopy.

\begin{tabular}{lll}
\hline SAR Stereoscopic Pair & CSK 2/3 & TSX 1 \\
\hline Perpendicular Baseline (km) & 248 & 190 \\
Time Baseline (day) & 5 & 5 \\
Intersection Angle $\left(^{\circ}\right)$ & 20.196 & 19.935 \\
Ratio $\frac{B_{\perp}}{H}$ & 0.40 & 0.37 \\
Height Ambiguity (m) & 5.01 & 3.48 \\
Cross-correlation & $0.62 \pm 0.12$ & $0.60 \pm 0.11$
\end{tabular}

Currently, there are scientific and commercial tools available for radargrammetric applications. In this research, the radargrammetric models implemented in commercial SARscape and PCI Geomatics (Toutin's model) software were used that consider the coherent properties of the radar and physical restrictions, respectively (Fig. 5). A trial full license of the PCI Geomatics version 2016 and temporary license of the SARscape version 5.2.1, developed by PCI Geomatics and SARMAP, respectively, were available for this research.

The SARscape and Toutin radargrammetric models recommend the use of stereoscopic pairs with at least $15^{\circ}$ intersection angles $(\Delta \theta)$ (PCI Geomatics, 2016; SARMAP, 2016). However, the critical step in the radargrammetric process is the acquisition of SGCPs, which must have accurate ground coordinates and an altimetric range that is well distributed.

To evaluate the vertical error, DSMs were generated from the two
SAR data types and through the two different radargrammetric approaches using the minimum possible number of SGCP (3 for the SARscape model and 8 for the PCI Geomatics) and the recommended number of 12 SGCPs for both.

\subsubsection{Sarscape's model}

The SARscape model generates radargrammetric DSMs from a known topographic surface (previous reference) tied by master and slave co-registered SAR scenes. The topography is estimated during the matching process using the cross-correlation at amplitude and subsequent solution by Range-Doppler equations for a SAR dual acquisition (SARMAP, 2016). In the SARscape's model, the normalized cross-correlation and the adjustment performed by Range-Doppler equations have a key role in the process, as described by Goblirsch and Pasquali (1996).

$$
\left\{\begin{array}{c}
\Delta R=R_{q}-R_{p}=\Delta \varphi \lambda / 4 \pi \\
\left|p_{t}\left(t_{p}\right)-x_{t}\left(t_{p}\right)\right|=R_{p} \\
\left(x_{v}\left(t_{p}\right)-p_{v}\left(t_{p}\right)\right) \cdot\left(p_{t}\left(t_{p}\right)-x_{t}\left(t_{p}\right)\right)=R_{p}\left|x_{v}\left(t_{p}\right)-p_{v}\left(t_{p}\right)\right| \operatorname{sen} \Psi_{p} \\
\left|q_{t}\left(t_{q}\right)-x_{t}\left(t_{q}\right)\right|=R_{q} \\
\left(x_{v}\left(t_{q}\right)-q\left(t_{q}\right)\right) \cdot\left(q_{t}\left(t_{q}\right)-x_{t}\left(t_{q}\right)\right)=R_{q}\left|x_{v}\left(t_{q}\right)-q_{v}\left(t_{q}\right)\right| \operatorname{sen} \Psi_{q}
\end{array}\right.
$$

where $R_{p}, R_{q}$ are the pixels contained on master and slave images; $\Delta \varphi$ is the wrapped phase difference; $\lambda$ is the wavelength; $x_{t}$ is the ground point position $(\mathrm{x}, \mathrm{y}, \mathrm{z}) ; x_{v}$ is the velocity on the ground point; $p_{v}\left(t_{p}\right), q_{v}\left(t_{q}\right)$ are the velocity of the antenna on master and slave acquisitions; $p_{t}\left(t_{p}\right), q_{t}\left(t_{q}\right)$ are the antenna positions on the master and 


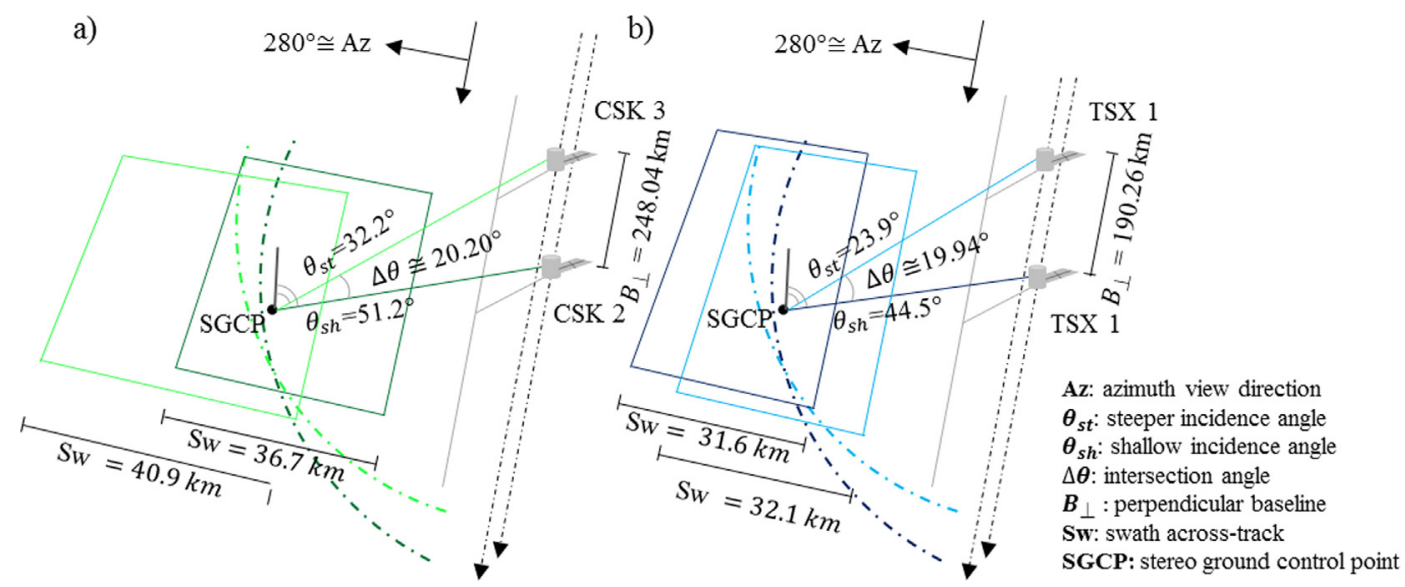

Fig. 4. Acquisition geometry for radargrammetry purposes used for (a) CSK dataset, obtained between April 2 to 7, 2016, and (b) TSK dataset from 25 to 30 March 2016.

slave acquisitions; and $\Psi_{p}, \Psi_{q}$ are the squint angles processed on the path of master and slave acquisitions.

In the SARscape process, the master and slave images were defined as a function of the incidence angle. Acquisitions with shallow angles were set as the reference images and the multilook and pixel spacing were derived from master images. The cross-correlation threshold and the SGCP measured have significant effects on accuracy, so it was applied to the cross-correlation threshold with 0.2 to co-register and 0.3 to estimate the shift parallax on the matching process. The process was developed with 12 SGCP as full performance and 3 SGCP as minimum performance.

The shift to height conversion was carried out to estimate absolute height over the mean sea level. The stereoscopic pairs retrieved the geocoded coordinates with 5 looks for CSK and 6 looks for TSX, both of them resampled on the ground at $12 \mathrm{~m}$.

\subsubsection{Toutin's model}

The radargrammetric tool implemented in PCI Geomatics is based on the orientation model developed by Toutin. This model performs a three-dimensional reconstruction based on precise metadata information and geometric-physical characteristics to generate the epipolar geometry considering the cross-correlation criteria, the modeling of distortions, ephemerides, time integration, geoid-ellipsoid references and cartographic projection (PCI Geomatics, 2016).

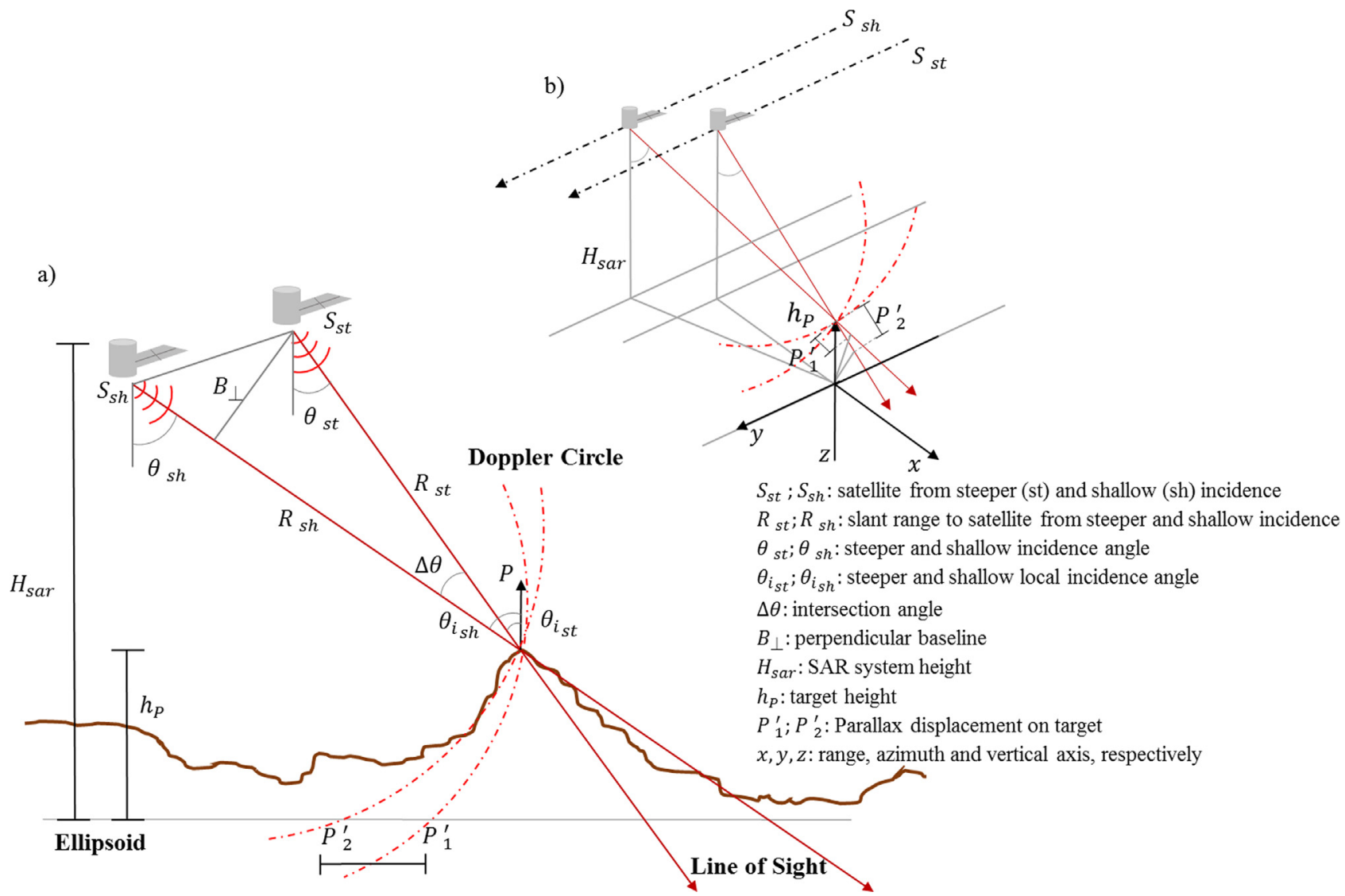

Fig. 5. The same-side approach of radargrammetry used on this study, showing the relative parallax displacement in the range direction which it was projected on an ellipsoid of reference (a) and on the slant range (b). Adapted from Woodhouse (2006) and Méric et al. (2009). 

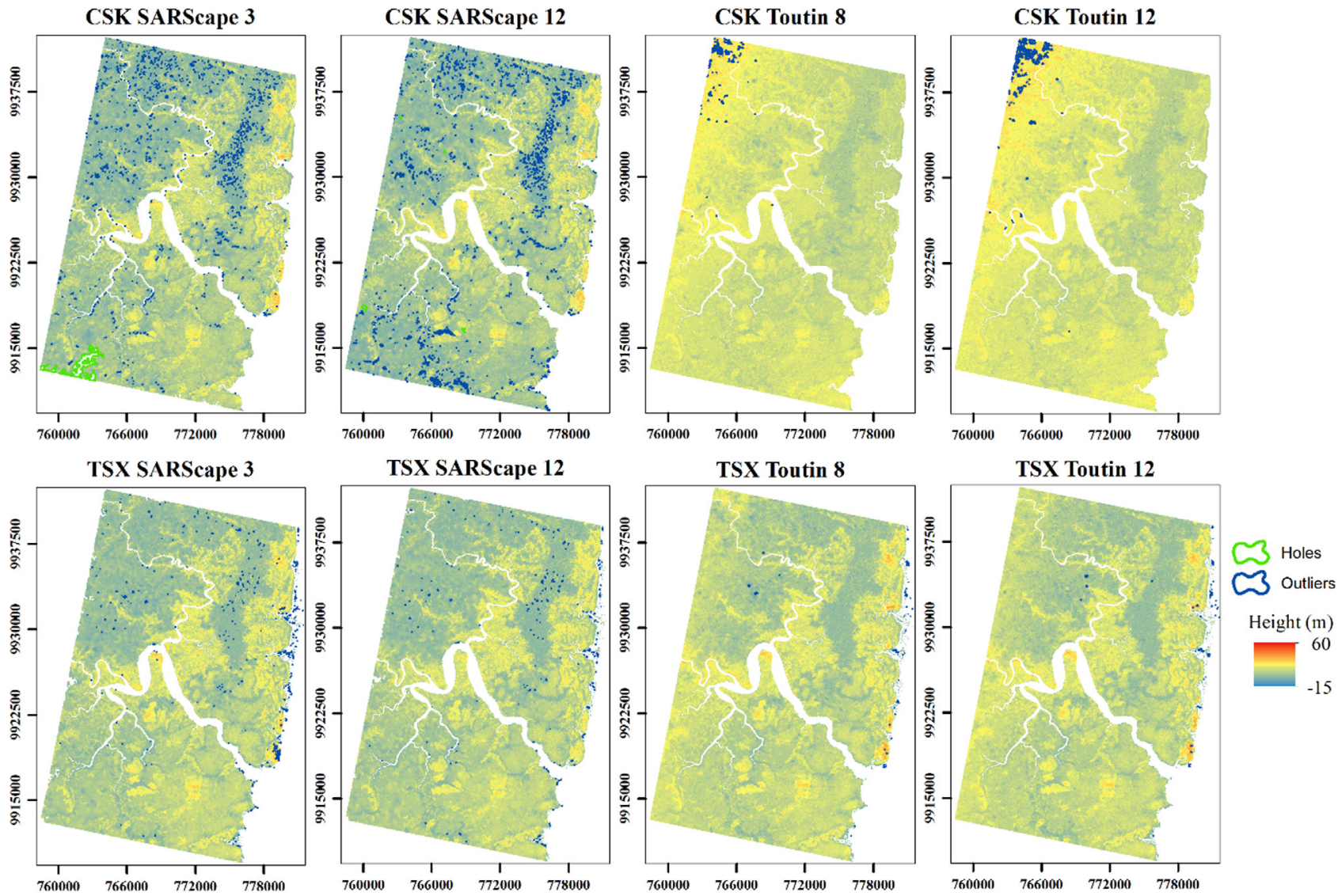

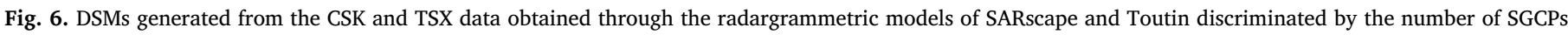
used (minimal: 3 for SARscape and 8 for Toutin; recommended: 12 for both).

Toutin's rigorous mathematical model considers principles of collinearity and coplanarity to compensate geometric distortions and calculate position and orientation in the SAR image, using at least 8 unknown parameters, according to Toutin (2004).

where $H$ is the altitude of the point corrected for Earth curvature; $H_{o}$ is satellite elevation; $N_{0}$ is the normal to the ellipsoid; $a$ is a parameter related to Earth's rotation; $\alpha$ is the instantaneous field of view on the image pixel; $p, q$ are the image coordinates; $x, y, h$ are the ground coordinates; $P, Q$ are the scale factors along and cross track; $\tau, \theta$ are the leveling angles along and cross track; $\Delta T, \Delta R$ are non-linear variations in attitude; and $b, c, \chi, \delta_{\gamma}$ are 2 nd order parameters referring to platform, sensor, Earth and cartographic projection.

Toutin's model uses epipolar or quasi-epipolar images to find homologous targets and solve the three-dimensional reconstruction. For this, it is necessary to consider a reasonable amount of control points, so DSMs were generated using 12 and 8 SGCPs. The terrain type was flat and the SLC scenes were under sampled to transpose speckle that yielded the cells of 5 and 6 looks using $12 \mathrm{~m}$ on the ground for CSK and TSX, respectively.

\subsection{Vertical accuracy analysis}

The radargrammetric DSMs generated by the CSK and TSX datasets were evaluated for vertical accuracy from the statistical tests performed between the ground GNSS measurements and the heights estimated by the models, which allowed for the calculation of discrepancies, trends and precision. In addition, the Taylor and Target plots applied for vertical precision were also analyzed. This evaluation was performed for the complete validation sample (40 ICPs), provided by GNSS and considered each Amazon coastal environment and was applied to 14 ICPs measured for the Coastal Plateau, 13 ICPs for the Fluvial Marine
Plain, and 13 ICPs for the Fluvial Marine Terrace.

The bias and precision analysis included the discrepancies $(\Delta Z)$,given by the difference between the estimated and measured heights, average $(\overline{\Delta Z})$, standard deviations $\left(\sigma_{\Delta Z}\right)$ and root mean square error (RMSE). The RMSE can derive the linear error at $90 \%$ of confidence level (LE90) that provides an expectation for error behavior on the cartographic product (Galo and Camargo, 1994).

$\left\{\begin{array}{c}R M S E=\sqrt{1 / n \sum_{i=1}^{\mathrm{n}}\left(Z_{\text {est }}-Z_{\text {meas }}\right)^{2}} \\ L E 90=1.6459 R M S E\end{array}\right.$

where $Z_{\text {est }}, Z_{\text {meas }}$ are the estimated and measured heights and $n$ is the number of pairs.

The Taylor and Target diagrams provide a broader view of the vertical error by means of the graphical representation of normalized bias $\left(B^{*}\right)$, normalized standard deviation $\left(\sigma^{*}\right)$, linear correlation $(\rho)$ and normalized unbiased RMSE ( $u R M S E^{*}$ ). The Taylor diagram shows these statistical indicators in polar coordinates, where $\sigma^{*}$ is the radial distance on the abscissa axis and $\rho$ is the angular position. This diagram also indicates the distance between an estimated model and a reference (measure proportional to $u R M S E^{*}$ ) (Taylor, 2001) and allows for the interpretation that a lower vertical error is associated with less bias and a high correlation.

$\left\{\begin{array}{c}\sigma^{*}=\sigma_{\text {est }} / \sigma_{\text {meas }} \\ \rho=\frac{1 / n \sum_{i=1}^{n}\left(Z_{\text {est }}-\bar{z}_{\text {est }}\right)\left(z_{\text {meas }}-\bar{z}_{\text {meas }}\right)}{\sigma_{\text {est }} \sigma_{\text {meas }}}\end{array}\right.$

where $Z \bar{z}, \sigma$ are the estimated height, mean and standard deviation, respectively, while the indexes meas and est indicate the values measured and estimated by the model.

The Target diagram provides a complementary view of the correlation and the RMSE (Jolliff et al., 2009), indicating the bias and the 
magnitude of the error, from the distances of the $B^{*}$ and $u R M S E^{*}$ in relation to a reference centered on $(0,0)$. These indicators are displayed on the Cartesian plane and can be described as:

$\left\{\begin{aligned} B^{*} & =\left(\frac{\bar{z}_{\text {est }}-\bar{z}_{\text {meas }}}{\sigma_{\text {meas }}}\right) \\ u R M S E^{*} & =\sqrt{1+\sigma^{*^{2}-2 \sigma^{*} \rho}}\end{aligned}\right.$

where $B^{*}$ is the normalized bias; $Z_{\text {est }}, Z_{\text {meas }}, \sigma_{\text {meas }}$ are the estimated and measured height and measured standard deviation; $u R M S E^{*}$ is the normalized unbiased RMSE; $\rho$ is the correlation; and $\sigma^{*}$ is the normalized standard deviation.

\section{Results and discussion}

The DSMs generated from Cosmo-SkyMed (CSK) and TerraSAR-X (TSX) Stripmap datasets, using both Toutin's and SARscape's radargrammetric models and the minimum and recommended number of the stereo ground control points (SGCPs) for each approach, are shown in Fig. 6.

Regardless of the approach or dataset used, the radargrammetric DSMs had difficulty representing continuous surfaces of low altitudes, flooded areas and flat to smooth relief. This occurred mainly in areas without SGCPs (Fig. 2a) and near large water bodies, which can be observed in Fig. 6 by the generation of lost values (holes) and outliers (heights below -8 and above $40 \mathrm{~m}$ ) and by the amplitude and spatial distribution of the altitudes. To minimize this issue, it is necessary to collect a stereoscopic pair in another passing (ascending) and carry out a fusion between the DSMs.

\subsection{General vertical accuracy of the radargrammetric DSMs}

The vertical accuracy of the DSMs generated from CSK and TSX datasets by Toutin's and SARscape's radargrammetric models using 12 SGCP as full performance and 3-8 SGCP as minimum performance (Fig. 6) was first assessed using 40 independent control points (ICPs). The absolute vertical error is presented as statistical parameters such as discrepancies, RMSE and LE90 per DSMs in Table 3.

The DSMs vertical discrepancies resulted in positive values for mean discrepancies $(\overline{\Delta Z})$. The different SAR datasets supplied the RMSE values from 4.34 to $7.76 \mathrm{~m}$ for CSK and 4.75 to $5.04 \mathrm{~m}$ for TSX. Similarly, the LE90 values ranged from 7.14 to $12.76 \mathrm{~m}$ and 7.82 to $8.29 \mathrm{~m}$ for CSK and TSX, respectively. Indeed, the DSMs generated from the TSX data were more adequate than those produced by the CSK data, when considering the models with the largest errors and discrepancies. The CSK had the best and the worst RMSE, while the TSX had more stability, which may be associated with its orbital and temporary parameters, as reported by Schubert et al. (2012).

There was a remarkable difference in the amount of the 5-day rain accumulated between CSK and TSX pair acquisition, of the order of $51.0 \mathrm{~mm} \cdot \mathrm{day}^{-1}\left(60.8-9.8 \mathrm{~mm} \cdot \mathrm{day}^{-1}\right) 20.4 \mathrm{~mm} \cdot \mathrm{day}^{-1}(20.3$ $-40.7 \mathrm{~mm} \cdot \mathrm{day}^{-1}$ ) respectively (Table 1 ). Although this did not represent a significant loss of the cross-correlation at amplitude above 0.60 for both datasets, as indicated in Table 2, the TSX data had the lowest cross-correlation at amplitude and recorded the peak of $9.0 \mathrm{~mm} \cdot \mathrm{h}^{-1}$ during the one of SAR acquisitions. In fact, there were not severe rain rates during the acquisitions on this study, Marzano et al. (2010, 2011) retreived precipitation from backscatter in X-band in such way that low and high rain rates had an RMSE less than $15 \mathrm{~mm} \cdot \mathrm{h}^{-1}$ to $25 \mathrm{~mm} \cdot \mathrm{h}^{-1}$.

The SARscape's and Toutin's radargrammetric models defined RMSE values in the intervals between $4.34-5.04 \mathrm{~m}$ and $5.01-7.76 \mathrm{~m}$, respectively. The SARscape model obtained a vertical accuracy better than Toutin's model, regardless of the SAR system, with RMSE of $4.34 \mathrm{~m}$ for the CSK dataset and $4.75 \mathrm{~m}$ for the TSX data, both using 12 SGCPs. The SARscape model adopts a pyramidal strategy given by multiple windows that have the advantage of combining the elevation surface by using several looks during the stereoscopic matching. However, any incompatibilities related to the signal-to-noise ratio, speckle or outliers can perform small errors on a high pyramid level, and these can be propagated for lower levels causing a large error mostly in flat terrains, as verified by Meric et al. (2011) and Balz et al. (2013). The choice of SGCP had direct implications on the vertical accuracy of SARscape's model, so it showed minor discrepancies in the same relief conditions when compared with Toutin's model.

On the other hand, Toutin's model generated the best model by the TSX dataset (RMSE of $5.01 \mathrm{~m}$ ) and the worst model from CSK $(7.76 \mathrm{~m})$, both using 12 SGCPs. Toutin's model is based on the epipolar geometry that reduces the complexity to match SAR images and it has proven a great gain of accuracy by combining strictly Range-Doppler equations with sensor modeling (state vector, radiometry and geocoding) that was more suitable on TSX than CSK, according to with Gutjahr et al. (2014).

Despite the SARscape model having better results for RMSE, Toutin's model has shown consistent experimental results for the radargrammetry, consistent with the previous studies by Toutin and Chenier (2009), Oliveira et al. (2011) and Capaldo et al. (2011, 2015) concerned with measuring disparities in types of relief and SAR systems; these studies achieved an RMSE between $3.5 \mathrm{~m}$ and $6.7 \mathrm{~m}$.

The mapping potential for all DSMs was better than DEMs from open sources and DSMs elaborated in previous studies, specifically, in terms of absolute vertical error, spatial resolution and data updates available (Table 4). To confirm this, Farr et al. (2007), Tachikawa et al. (2011), Forkuor and Maathuis (2012) and Szabó et al. (2015) applied the SRTM and/or ASTER GDEM in several kinds of land cover and relief that achieved the RMSE on the order of $2.55-18.8 \mathrm{~m}$, in addition, Paradella et al. (2003, 2005a, 2005b), Oliveira et al., (2011, 2012) and Pereira et al. (2014) applied the Radarsat Specific Model (RSM) and Toutin radargrammetric models in different kinds of terrain and found an RMSE between $5.0 \mathrm{~m}$ and $35.9 \mathrm{~m}$.

Taylor's and Target's diagrams allowed ordering of the eight models based on standardized vertical error parameters estimated from all field-measured ICPs (40). The DSMs generated from the CSK dataset and Toutin's model were closer to the reference in the Taylor diagram, whereas the same data type (CSK), however using the SARscape model,

Table 3

The vertical accuracy for radargrammetric DSMs based on discrepancies, RMSE and LE90.

\begin{tabular}{|c|c|c|c|c|c|c|c|c|}
\hline SAR & Models & SGCP & $\Delta Z_{\min }(\mathrm{m})$ & $\Delta Z_{\max }(\mathrm{m})$ & $\overline{\Delta Z}(\mathrm{~m})$ & $\sigma_{\Delta Z}(\mathrm{~m})$ & RMSE (m) & LE90 (m) \\
\hline \multirow[t]{4}{*}{ CSK } & SARscape & 3 & -9.96 & 10.97 & 0.64 & 4.39 & 4.38 & 7.21 \\
\hline & & 12 & -8.10 & 11.09 & 0.05 & 4.40 & 4.34 & 7.14 \\
\hline & Toutin & 8 & -0.17 & 11.99 & 6.83 & 2.61 & 7.31 & 12.02 \\
\hline & & 12 & 2.93 & 12.93 & 7.33 & 2.58 & 7.76 & 12.76 \\
\hline \multirow[t]{4}{*}{ TSX } & SARscape & 3 & -2.97 & 11.93 & 2.96 & 4.13 & 5.04 & 8.29 \\
\hline & & 12 & -3.41 & 10.32 & 2.58 & 4.05 & 4.75 & 7.82 \\
\hline & Toutin & 8 & -2.58 & 12.51 & 3.64 & 3.51 & 5.03 & 8.27 \\
\hline & & 12 & -2.35 & 12.45 & 3.58 & 3.55 & 5.01 & 8.24 \\
\hline
\end{tabular}


Table 4

The radargrammetric DSMs elaborated from different SAR systems and the DEMs from open sources which were assessed in Brazilian landscapes.

\begin{tabular}{|c|c|c|c|c|c|}
\hline Author & Data & Model & Environment & Terrain & RMSE (m) \\
\hline Paradella et al. (2005a) & Radarsat-1 & RSM & Amazon Forest & Mountain & $20.1-34.0$ \\
\hline Paradella et al. (2005b) & Radarsat-1 & RSM & Amazon Forest & Flat & $14.6-35.9$ \\
\hline Oliveira et al. (2011) & TSX & Toutin & Amazon Forest & Mountain & $6.4-6.7$ \\
\hline Oliveira et al. (2012) & Radarsat-2 & Toutin & Tropical Semiarid & Valley & $5.0-6.2$ \\
\hline Pereira et al. (2014) & Radarsat-1 & RSM & Amazon Coast & Flat & 9.5 \\
\hline \multirow[t]{4}{*}{ This study } & ASTER & - & Amazon Coast & Flat & 10.3 \\
\hline & AW3D & - & Amazon Coast & Flat & 4.8 \\
\hline & SRTM & - & Amazon Coast & Flat & 5.7 \\
\hline & CSK, TSX & SARScape, Toutin & Amazon Coast & Flat & $4.3-7.8$ \\
\hline
\end{tabular}

a)

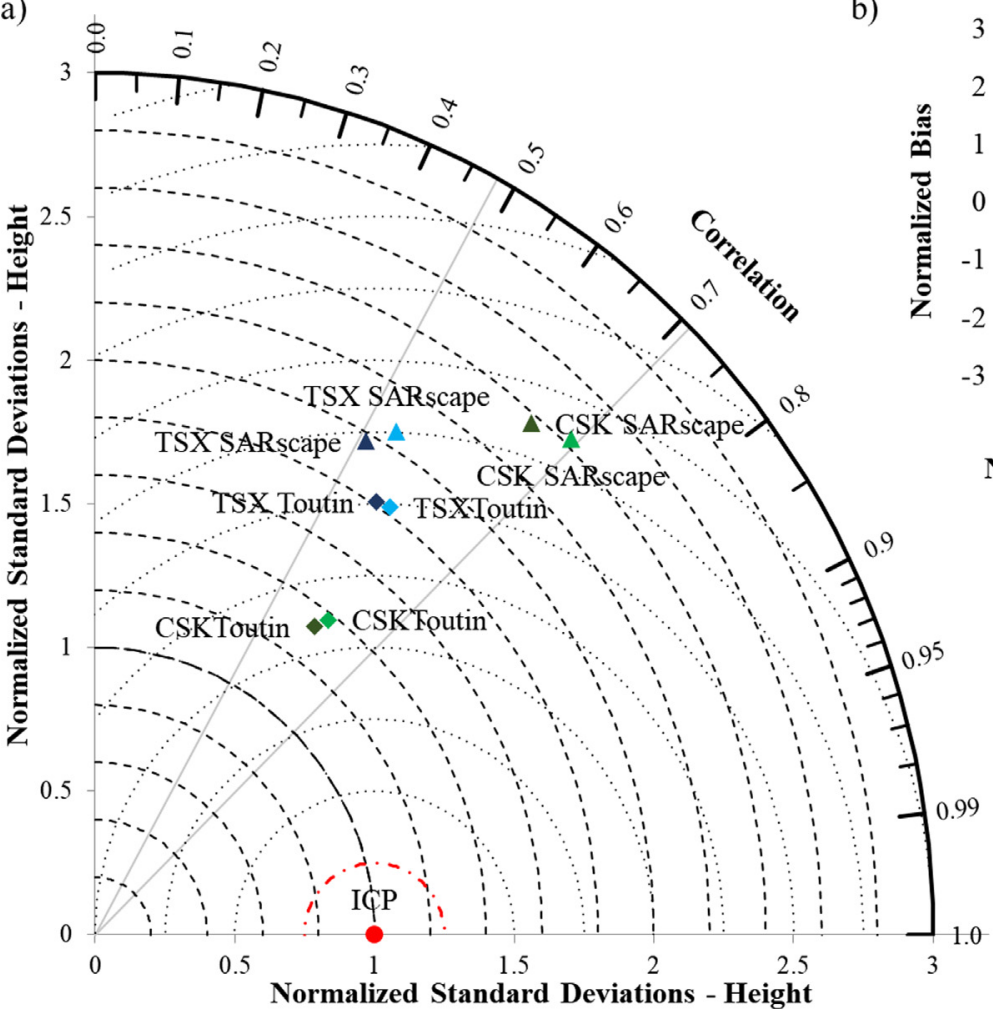

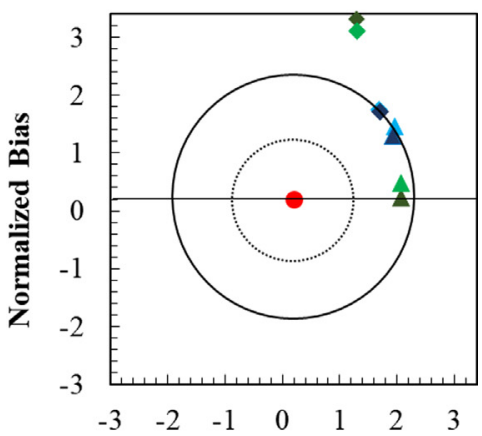

Normalized Unbiased RMSE

- ICPs

$\triangle$ CSK SARscape 3

- CSK SARscape 12

- CSK Toutin 8

- CSK Toutin 12

4 TSX SARscape 3

A TSX SARscape 12

- TSX Toutin 8

TSX Toutin 12

Fig. 7. Representation of the vertical error of the radargrammetric DSMs by means of: (a) Taylor diagram, indicating the normalized standard deviation ( $\sigma^{*}$ ) and

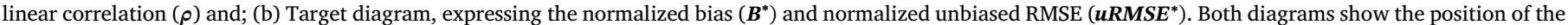
error parameters in relation to a reference (ICPs surveyed by GNSS).

was less biased according to the Target diagram (Fig. 7).

As shown in Fig. 7(a), the CSK SARscape DSMs defined the positions farthest from the reference since they produced the highest normalized standard deviation $\left(\sigma^{*}\right)$ with $2.37 \mathrm{~m}$ (using 12 SGCPs) and $2.46 \mathrm{~m}(3$ SGCPs) and the strongest correlation (0.7 and 0.66 , respectively) and were the least accurate. In contrast, CSK Toutin DSMs were closer to the reference ICP, with the lowest $\sigma^{*}(1.33 \mathrm{~m}$ with 12 SGCPs and $1.38 \mathrm{~m}, 8$ SGCPs) and the second largest $\rho$ (0.59 and 0.61 , respectively), which means that the dispersion has more impact on model performance than linear association.

Considering the Target diagram of Fig. 7(b), the CSK Toutin DSMs overestimated the altitude, with a normalized bias $\left(B^{*}\right)$ of 2.90 and 3.11 for 8 and 12 SGCPs, respectively, producing the farthest position from the reference ICP. These DSMs also recorded positive values for the $u R M S E^{*}$ (1.11 and 1.09), which are $\sigma_{\text {est }}>\sigma_{\text {meas }}$ on the abscissas axis. The TSX radargrammetric DSMs were in an intermediate position, indicating that the altitude was overestimated ( $B^{*}$ between 1.09 and 1.54), anduRMSE* was between 1.49 and 1.75 .

\subsection{Amazon coastal environments}

The radargrammetric DSMs allowed for describing the Amazonian coastal environments by their attributes of vertical error, class and cross-correlation, thereby the sampling strategy adopted in the field work considered the acquisition of a minimum number of ICPs for each environment. The description of the vertical error through discrepancy $(\Delta Z)$ and RMSE by coastal environment is presented in Fig. 8.

For all radargrammetry models, the greatest amplitude in the vertical error occurred in the Fluvial Marine Plain, with a total variation defined in the interval of -5.03 to $12.93 \mathrm{~m}$, related to the effect of the irregular mangrove canopy that occurs mainly in this coastal environment. The smallest vertical errors occurred in the Costal Plateau and Fluvial Marine Terrace, with $\Delta \mathrm{Z}$ varying from -5.66 to $11.90 \mathrm{~m}$ and -8.10 to $12.45 \mathrm{~m}$, and an RMSE from 3.89 to $7.48 \mathrm{~m}$ and 3.79 to $6.76 \mathrm{~m}$, respectively. These latter environments are characterized by lower forest cover with some trees in the upper canopy, bare soil, natural fields and agriculture, as well as artificial structures and urban areas. 

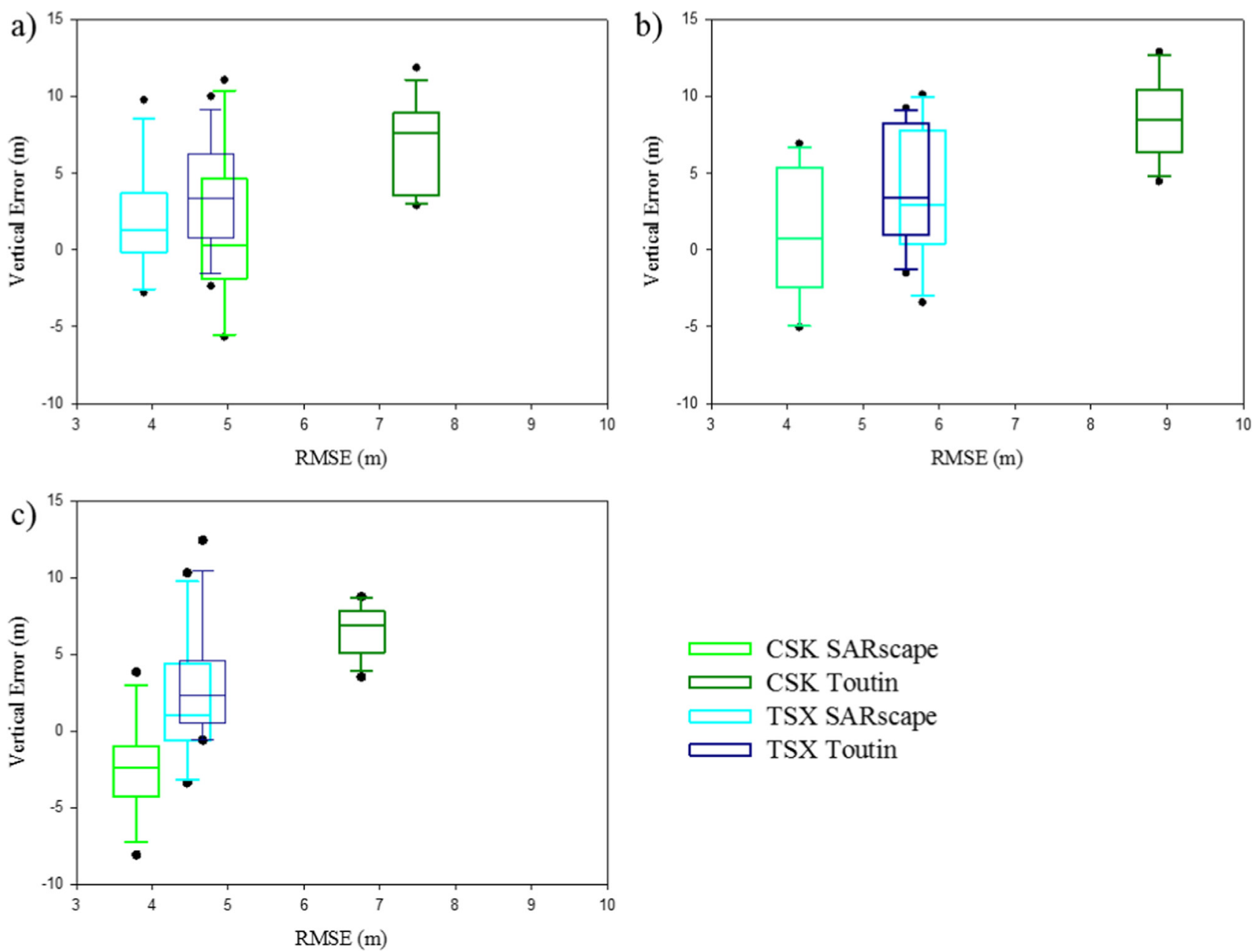

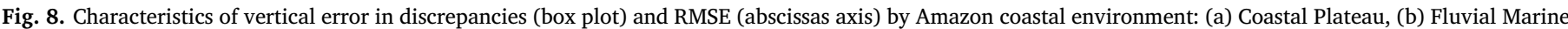
Plain, and (c) Fluvial Marine Terrace.

Despite the greatest source of vertical error being related to the variation of slope (Toutin, 2002; Szabó et al., 2015), the characteristics of the Amazon coastal landscape had an influence on the vertical error behavior of radargrammetric DSMs, as has been observed in the TanDEM-X (Wessel et al., 2014) and SRTM (Rodríguez et al., 2006).

The sources of errors are distributed by areas of mangroves, intertidal flats, mud flats, salt marshes, cliffs and sandy bars. The occurrence of vertical errors along the shorelines, tidal channels and cliffs, specifically in the contact between the water body and the coastal relief was remarkable. This suggests a demand for more accurate SAR systems with higher spatial resolution in order to increase the level of cartographic detail.

Considering that the cross-correlation at amplitude $\left(\gamma_{i}\right)$ is a requirement for epipolar correspondence of stereo pairs and, therefore, in the generation of radargrammetric models, a graph was elaborated relating this parameter to the RMSE (Fig. 9).

The highest $\gamma_{i}$ of 0.69 occurred for the Fluvial Marine Plain associated with a vertical error of $5.78 \mathrm{~m}$, while the lowest cross-correlation ( $\gamma_{i}$ of 0.53 ) occurred for the Coastal Plateau with a vertical error of $4.77 \mathrm{~m}$. The Fluvial Marine Plain has areas covered by dense mangrove vegetation which maintained high values of $\gamma_{i}$. This configured the main advantage of the radargrammetry in the Amazon coastal environments with incoherent behavior.

The $\gamma_{i}$ is a requirement for epipolar matching of stereo pairs but this parameter alone does not guarantee vertical accuracy. Toutin's model suggested more tolerance for solving pixels with low values of $\gamma_{i}$, whereas SARscape's model suggested the lowest vertical error and the

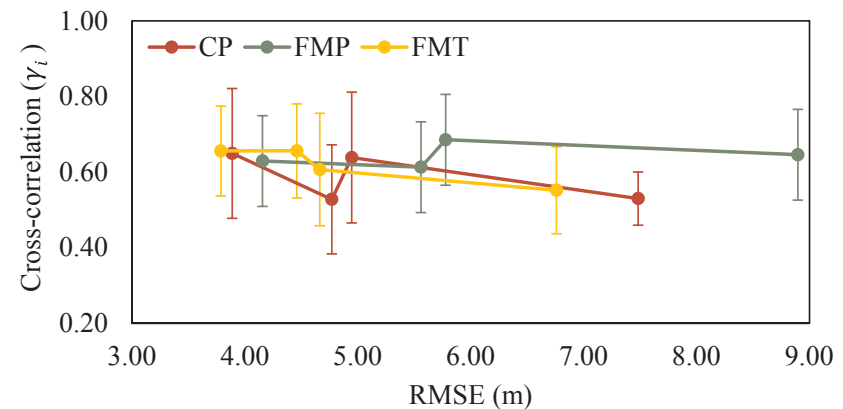

Fig. 9. The Coastal Plain (CP), Fluvial Marine Plain (FMP) and Fluvial Marine Terrace (FMT) were characterized by cross-correlation at amplitude and vertical RMSE that defined a linear trend using the reference by GNSS surveys.

terrain detail in the edges, shape and aspect. However, the general incoherent behavior of the Amazon coastal environments is the main advantage of radargrammetry in the DSMs generation, in relation to the SAR interferometry approach.

The Taylor and Target diagrams are also applied for vertical precision analysis of the CSK and TSX DSMs generated from the radargrammetric models of SARscape and Toutin using 12 SGCPs, and considering each Amazon coastal environment (Fig. 10). In this evaluation, 14 ICPs were measured for the Coastal Plateau, 13 ICPs for the Fluvial Marine Plain, and 13 ICPs for the Fluvial Marine Terrace.

Taylor's diagram in Fig. 10(a) shows that the Fluvial Marine Plain 


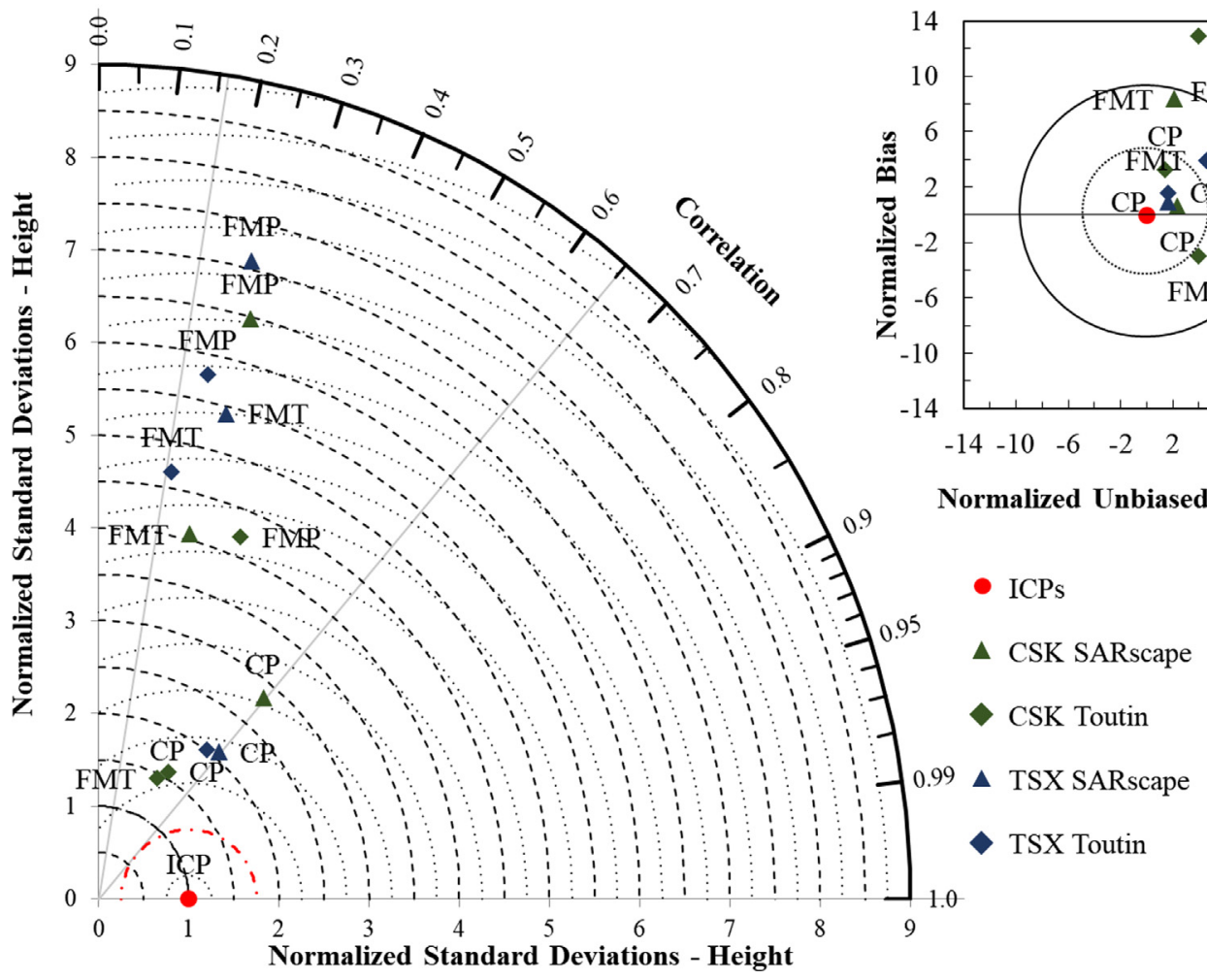

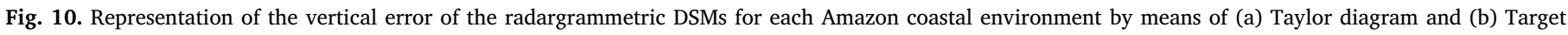
diagram. FMP refers to Fluvial Marine Plain; CP is Coastal Plateau and FMP is Fluvial Marine Terrace.

produced the highest standard deviation $\left(\sigma^{*}\right)$, ranging from $4.21 \mathrm{~m}$ to $7.08 \mathrm{~m}$, and poor correlation (between 0.21 and 0.37 ). The high $\sigma^{*}$ and low $\rho$ are due to the presence of tall trees with larger crowns in the mangrove vegetation, pointing to the complexity of this environment in terms of altimetric mapping. With values closer to the reference in the Taylor diagram, the DSMs of the Coastal Plateau environment resulted in lower $\sigma^{*}$, between 1.57 and $2.83 \mathrm{~m}$, and higher correlations (between 0.49 and 0.64 ). The smaller error indicators suggest that the altimetric mapping is favored by homogeneous areas such as bare soils, deforested areas and artificial structure features of this environment. The Fluvial Marine Terrace obtained an intermediate position in the plot, with the $\sigma^{*}$ ranging from 1.46 to $5.42 \mathrm{~m}$, and correlations between 0.17 and 0.45 .

From the target diagram (Fig. 10(b)), it can be noted that the Fluvial Marine Plain was the coastal environment that most overestimated the DSMs altitudes, with $B^{*}$ varying from 1.67 to $12.88 \mathrm{~m}$. The Fluvial Marine Terrace was the only underestimated altitude value ( $B^{*}$ equal to $-2.99 \mathrm{~m}$ ), while the other coastal environments defined overestimated values ranging from $0.60 \mathrm{~m}$ to $12.88 \mathrm{~m}$. The dispersion of vertical errors in coastal environments exceeded the initial dispersion provided by ICPs with $u R M S E^{*}$ between 1.39 and $6.91 \mathrm{~m}$, meaning that the estimated variability was greater than the measured variability $\left(\sigma_{\text {est }}>\sigma_{\text {med }}\right)$. Fluvial Marine Plateau and Fluvial Marine Terrace defined the greatest variability, with $u R M S E^{*}$ varying from 3.95 to $6.91 \mathrm{~m}$ and 2.11 to $5.25 \mathrm{~m}$, respectively. The Coastal Plateau had the nearest location to the center of the Target diagram, with $B^{*}$ ranging from 0.60 to $3.23 \mathrm{~m}$ and $U R M S E^{*}$ between 1.39 and $2.32 \mathrm{~m}$.

\section{Conclusions}

The CSK and TSX datasets allowed for the production of radargrammetric DSMs of the flat relief of the Amazon coastal environment with an almost continuous surface, using both the SARscape model and
Toutin's model. It was verified that the vertical error of the DSMs varied with the type of coastal environment analyzed.

The vertical accuracy accomplished similar performances for CSK and TSX, in which the RMSE shared intervals between $4.34-7.76 \mathrm{~m}$ and 4.75-5.04 m, respectively. The most precise DSM was given by CSK and the lowest variability of vertical error was given by TSX. There were accuracy fluctuations that alternated the CSK and TSX under the analyses developed by Taylor's and Target's diagrams but TSX shall be considered more stable for the statistics used.

A similar performance, in terms of RMSE, is also observed when comparing the SARscape and Toutin radargrammetric models that have achieved accuracies between $4.38-5.04 \mathrm{~m}$ and $5.01-7.76 \mathrm{~m}$, respectively. Toutin's model seems to keep the variability of the error under control in relation to SGCP given on a matching process; however, it defined DSMs with higher RMSEs and greater bias than SARscape. The SARscape model developed DSMs that were more detailed on the shape of relief and the spatial resolution that maintained the extraction of elevation finer than Toutin's model; hence, it had a lower RMSE. The SARscape and Toutin models proved to be robust tools to carry out radargrammetry, whereas a larger cross-correlation at amplitude and SAR precise geometry tend to reduce dependence on a large number of SGCPs.

The Coastal Plateau and Fluvial Marine Terrace were the Amazon coastal environments that defined more precise, vertical accuracies and, regardless of the SAR system or radargrammetric model used, reached the lowest RMSE (less than $7.5 \mathrm{~m}$ ). Therefore, the three-dimensional mapping of the Fluvial Marine Plain coastal environment was the most complex, especially in the mangrove areas and shoreline. Even so, the RMSE obtained for this environment was better than $8.90 \mathrm{~m}$. It was noted the Coastal Plateau was more suitable to radargrammetry considering the positions given by the Taylor and Target diagrams used.

The CSK and TSX SAR datasets and the SARscape and Toutin models were suitable for the tridimensional representation of the Amazon 
coastal environments, considering the acquisition of the $\mathrm{X}$ band during the rainy season and high amplitude of tides, with low to moderate incidence angles and the use of a reduced number of stereo ground control points. They demonstrated the potential to monitor the topography at a detailed level of the spatial and temporal scales.

The new initiatives for the flat relief of the Amazon coast should model the non-topographic artifacts (artificial and natural), geomorphometry of relief, the cartographic scale for planimetry and altimetry, and the opposite side SAR configuration. In addition, the radargrammetric approach needs to consider the mechanism of backscattering on the surface and to reduce the ground points dependence on favoring the orbit determination and cartographic reference.

\section{Acknowledgments}

The authors would like to thank the Graduate Program in Cartographic Sciences of São Paulo University (PPGCC/Unesp), Higher Education Personnel Improvement (CAPES), Brasília, Brazil and Agricultural and Forestry Studies Foundation (FEPAF), Botucatu, Brazil for the financial support for the field surveys with the scholarship. Thanks to Universidade Federal do Pará (UFPA) in the Department of Geology, for facilitating the use of their laboratories and to the Centro Gestor e Operacional do Sistema de Proteção da Amazônia for the institutional support during the doctoral research. This study counted on the technical support provided by the SARMAP team, therefore, a special thanks to Paolo Pasquali, Paolo Riccardi, Andrey Giardino, Daniele Lecci and Alessio Cantone. The comments by the anonymous reviewers were highly appreciated. The COSMO-SkyMed and TerraSARX SAR datasets were provided by the (CASI - Italian Space Agency, Roma, Italy - (2016) and CDLR - German Aerospace Centre, Cologne, Germany - (2016), under scientific projects identifications 201 and COA2686, respectively.

\section{References}

ASI, (Italian Space Agency), 2016. Calls and opportunities [WWW Document]. Ital. Sp. Agency. < http://www.asi.it/en/agency/calls-and-opportunities > (accessed 1. 15.16).

Balz, T., He, X., Zhang, L., Liao, M., 2009. TerraSAR-X stereo radargrammetry for precise DEM generation in South-East Asia. In: Proceedings of Asian Conference on Remote Sensing, Beijing, p. 4214.

Balz, T., Zhang, L., Liao, M., 2013. Direct stereo radargrammetric processing using massively parallel processing. ISPRS J. Photogramm. Remote Sens. 79, 137-146. https://doi.org/10.1016/j.isprsiprs.2013.02.014.

Bamler, R., 2000. Interferometric stereo radargrammetry: absolute height determination from ERS-ENVISAT interferograms. In: IGARSS 2000. IEEE 2000 International Geoscience and Remote Sensing Symposium. Taking the Pulse of the Planet: The Role of Remote Sensing in Managing the Environment. Proceedings (Cat. No.00CH37120). IEEE, pp. 742-745. https://doi.org/10.1109/IGARSS.2000.861689.

Capaldo, P., 2013. High Resolution Radargrammetry with COSMO-SkyMed, TerraSAR-X and RADARSAT-2 Imagery: Development and Implementation of an Image Orientation Model for Digital Surface Model Generation. Università di Roma.

Capaldo, P., Crespi, M., Fratarcangeli, F., Nascetti, A., Pieralice, F., 2011. High-resolution SAR radargrammetry: a first application with COSMO-SkyMed SpotLight imagery. IEEE Geosci. Remote Sens. Lett. 8, 1100-1104. https://doi.org/10.1109/LGRS.2011. 2157803.

Capaldo, P., Nascetti, A., Porfiri, M., Pieralice, F., Fratarcangeli, F., Crespi, M., Toutin, T., 2015. Evaluation and comparison of different radargrammetric approaches for digital surface models generation from COSMO-SkyMed, TerraSAR-X, RADARSAT-2 imagery: analysis of Beauport (Canada) test site. ISPRS J. Photogramm. Remote Sens. 100, 60-70. https://doi.org/10.1016/j.isprsjprs.2014.05.007.

Congalton, R.G., Green, K., 2009. Assessing the Accuracy of Remotely Sensed Data: Principles and Practices. CRC Press/Taylor \& Francis, New York.

Costa, J.B.S., Bemerguy, R.L., Hasui, Y., Borges, S., Roberto, C., Ferreira, P., Édson, P., Bezerra, L., Lima, M., Maria, J., Fernandes, G., 1996. Neotectônica Da Região Amazônica: Aspectos Tectônicos, Geomorfológicos E Deposicionais. Geonomos 4 $23-44$.

Crosetto, M., Pérez, F., 2000. Radargrammetry and SAR interferometry for DEM generation: validation and data fusion. SAR Work. CEOS Comm. Earth Obs. Satell 367-372.

DHN, (Diretoria de Hidrografia e Navegação), 2016. PREVISÕES DE MARÉS [WWW Document]. Dir. Hidrogr. e Naveg. < http://www.mar.mil.br/dhn/chm/boxprevisao-mare/tabuas/ > (accessed 4.30.16).

DLR, (German Aerospace Center), 2016. TerraSAR-X Science Service System [WWW Document]. Ger. Aerosp. Cent. < http://sss.terrasar-x.dlr.de/ > (accessed 1.20.16)
El-Robrini, M., Alves, M.A.M.., Souza Filho, P.W.M., El-Robrini, M.H.S., Silva Júnior, O. G., França, C.F., 2006. Atlas de erosão e progradação da zona costeira do Estado do Pará - Região Amazônica: Áreas oceânica e estuarina. In: Muehe, D. (Ed.), Atlas de Erosão E Progradação Da Zona Costeira Brasileira. São Paulo, pp. 1-34.

Farr, T.G., Rosen, P.A., Caro, E., Crippen, R., Duren, R., Hensley, S., Kobrick, M., Paller, M., Rodriguez, E., Roth, L., Seal, D., Shaffer, S., Shimada, J., Umland, J., Werner, M., Oskin, M., Burbank, D., Alsdorf, D., 2007. The shuttle radar topography mission. Rev. Geophys. 45, RG2004. https://doi.org/10.1029/2005RG000183.

Fayard, F., Meric, S., Pottier, E., 2007. Matching stereoscopic SAR images for radargrammetric applications. In: IEEE International Geoscience and Remote Sensing Symposium IEEE. pp. 4364-4367. https://doi.org/10.1109/IGARSS.2007.4423819.

Forkuor, G., Maathuis, B., 2012. Comparison of SRTM and ASTER derived digital elevation models over two regions in Ghana - implications for hydrological and environmental modeling. In: In: Piacentini, T., Miccadei, E. (Eds.), Studies on Environmental and Applied Geomorphology InTech, Rijeka, Croatia, pp. 219-240.

de França, C.F., Souza Filho, P.W.M., 2006. Compartimentação morfológica da margem leste da ilha de marajó: zona costeira dos municípios de soure e salvaterra - Estado do Pará. Rev. Bras. Geomorfol. 1, 33-42.

Galo, M., Camargo, P., 1994. Utilização do GPS no controle de qualidade de cartas. Congr. Bras. Cadastro 41-48.

Geyer, R.W., Beardsley, R.C., Lentz, S.J., Candela, J., Limeburner, R., Johns, W.E., Castro, B.M., Dias Soares, I., 1996. Physical oceanography of the Amazon shelf. Cont. Shelf Res. 16, 575-616. https://doi.org/10.1016/0278-4343(95)00051-8.

Goblirsch, W., Pasquali, P., 1996. Algorithms for calculation of digital surface models from the unwrapped interferometric phase. Proc. Int. Geosci. Remote Sens. Symp. 656-658.

Gutjahr, K., Perko, R., Raggam, H., Schardt, M., 2014. The epipolarity constraint in stereo-radargrammetric DEM generation. IEEE Trans. Geosci. Remote Sens. 52, 5014-5022. https://doi.org/10.1109/TGRS.2013.2286409.

He, X., Balz, T., Zhang, L., Liao, M., 2010. Stereo Radargrammetry in South-East Asia using TerraSAR-X. In: Wagner, W., Székely, B. (Eds.), ISPRS TC VII Symposium - 100 Years ISPRS. Viena, Austria, pp. 270-274.

IBGE, (Instituto Brasileiro de Geografia e Estatística), 2015. Downloads - Geociências [WWW Document]. Inst. Bras. Geogr. e Estatística. < http://downloads.ibge.gov.br/ downloads_geociencias.htm $>$ (accessed 4.25.15).

INMET, (Instituto Nacional de Meteorologia), 2016. Banco de Dados Meteorológicos para Ensino e Pesquisa [WWW Document]. Inst. Nac. Meteorol. < http://www.inmet.gov. br/portal/index.php?r = bdmep/bdmep $>$ (accessed 4.6.16).

Jolliff, J.K., Kindle, J.C., Shulman, I., Penta, B., Friedrichs, M.A.M., Helber, R., Arnone, R.A., 2009. Summary diagrams for coupled hydrodynamic-ecosystem model skill assessment. J. Mar. Syst. 76, 64-82. https://doi.org/10.1016/j.jmarsys. 2008.05.014.

Yu, Jung Hum, Ge, Linlin, Li, Xiaojing, 2014. Radargrammetry for digital elevation model generation using Envisat reprocessed image and simulation image. IEEE Geosci. Remote Sens. Lett. 11, 1589-1593. https://doi.org/10.1109/LGRS.2014.2301731.

Koyama, C.N., Gokon, H., Jimbo, M., Koshimura, S., Sato, M., 2016. Disaster debris estimation using high-resolution polarimetric stereo-SAR. ISPRS J. Photogramm. Remote Sens. 120, 84-98. https://doi.org/10.1016/j.isprsjprs.2016.08.003.

Leberl, F.W., 1990. Radargrammetric Image Processing. Artech House, Norwood MA.

Martorano, L.G., 1993. Estudos climáticos do estado do Pará, classificação climática (Koppen) e deficiência hídrica (Thornthwaite, Mather).

Marzano, F.S., Mori, S., Chini, M., Pulvirenti, L., Pierdicca, N., Montopoli, M., Weinman, J.A., 2011. Potential of high-resolution detection and retrieval of precipitation fields from X-band spaceborne synthetic aperture radar over land. Hydrol. Earth Syst. Sci. 15, 859-875. https://doi.org/10.5194/hess-15-859-2011.

Marzano, F.S., Mori, S., Weinman, J.A., 2010. Evidence of rainfall signatures on X-band synthetic aperture radar imagery over land. IEEE Trans. Geosci. Remote Sens. 48, 950-964. https://doi.org/10.1109/TGRS.2009.2034843.

Meade, R.H., Dunne, T., Richey, J.E., Santos, U De M., Salati, E., 1985. Storage and remobilization of suspended sediment in the lower Amazon river of Brazil. Science (80-.) 228, 488-490. https://doi.org/10.1126/science.228.4698.488.

Meric, S., Fayard, F., Pottier, É., 2011. A multiwindow approach for radargrammetric improvements. IEEE Trans. Geosci. Remote Sens. 49, 3803-3810. https://doi.org/10. 1109/TGRS.2011.2144606.

Méric, S., Fayard, F., Pottier, É., 2009. Radargrammetric SAR image processing. In: Geoscience and Remote Sensing INTECH Open Access Publisher, Rijeka, Croatia, pp. $421-454$.

Nascimento, W.R., Souza-Filho, P.W.M., Proisy, C., Lucas, R.M., Rosenqvist, A., 2013. Mapping changes in the largest continuous Amazonian mangrove belt using objectbased classification of multisensor satellite imagery. Estuar. Coast. Shelf Sci. 117, 83-93. https://doi.org/10.1016/j.ecss.2012.10.005.

Nittrouer, C.A., Kuehl, S.A., DeMaster, D.J., Kowsmann, R.O., 1986. The deltaic nature of Amazon shelf sedimentation. Geol. Soc. Am. Bull. 97, 444-458.

Nittrouer, C.A., Kuehl, S.A., Sternberg, R.W., Figueiredo, A.G., Faria, L.E.C., 1995. An introduction to the geological significance of sediment transport and accumulation on the Amazon continental shelf. Mar. Geol. 125, 177-192. https://doi.org/10.1016 0025-3227(95)00075-A.

O'Loughlin, F.E., Paiva, R.C.D., Durand, M., Alsdorf, D.E., Bates, P.D., 2016. A multisensor approach towards a global vegetation corrected SRTM DEM product. Remote Sens. Environ. 182, 49-59. https://doi.org/10.1016/j.rse.2016.04.018.

Oliveira, C.G., Paradella, W.R., da Silva, A. de Q., 2011. Assessment of radargrammetric DSMs from TerraSAR-X Stripmap images in a mountainous relief area of the Amazon region. ISPRS J. Photogramm. Remote Sens. 66, 67-72. https://doi.org/10.1016/j. isprsjprs.2010.08.008.

Oliveira, C.G., Paradella, W.R., Santos, A.R., Albuquerque, P.C.G., 2012. An assessment of the use of RADARSAT-2 for detailed topographic mapping in a tropical semiarid terrain of Brazil. Can. J. Remote Sens. 37, 472-483. https://doi.org/10.5589/m11- 
057.

Ouchi, K., 2013. Recent trend and advance of synthetic aperture radar with selected topics. Remote Sens.

Paradella, W.R., Cecarelli, I.C.F., Luiz, S., de Oliveira, C.G., Cottini, C.P., Okida, R., 2003. Produção de carta topográfica através da estereoscopia de alta resolução do RADARSAT-1 integrada com dados TM-LANDSAT 5: uma avaliação para terrenos planos na Floresta Nacional de Tapajós (PA). Brazil. J. Geol. 33, 99-110.

Paradella, W.R., Cecarelli, I.C.F., Luiz, S., de Oliveira, C.G., Okida, R., 2005a. Geração de Carta Topográfica com Estéreo-pares Fine do RADARSAT-1 e dados ETM + Landsat 7 em Ambiente Montanhoso na Região Amazônica (Serra dos Carajás, Pará). Rev. Bras. Geociências 34, 323-332.

Paradella, W.R., Mura, J.C., Gama, F.F., Santos, A.R., 2012. Radar interferometry in surface deformation detection with orbital data. Rev. Bras. Cartogr. 64, 797-811.

Paradella, W.R., Oliveira, C.G., Luiz, S., Cecarelli, I.C.F., Cottini, C.P., Okida, R., 2005b. Operational use of RADARSAT-1 fine stereoscopy integrated with Landsat-5 thematic mapper data for cartographic application in the Brazilian Amazon. Can. J. Remote Sens. 31, 139-148. https://doi.org/10.5589/m05-001.

PCI Geomatics, 2016. PCI Geomatics - Geomatica Help.

de Souza Pereira, E.A., Souza-Filho, P.W.M., Paradella, W.R., da Rocha Nascimento, W., 2014. Generation and evaluation of radargrammetric DEM from RADARSAT-1 standard images in low relief area in the Amazon coastal plain. Rev. Bras. Geofis. 32, 405-418.

Perko, R., Raggam, H., Deutscher, J., Gutjahr, K., Schardt, M., 2011. Forest assessment using high resolution SAR data in X-band. Remote Sens. 3, 792-815. https://doi.org/ $10.3390 /$ rs3040792.

Polidori, L., 1997. Cartographie Radar. Gordon and Breach Science Publishers, Amsterdam.

Raggam, H., Gutjahr, K., Perko, R., Schardt, M., 2010. Assessment of the stereo-radargrammetric mapping potential of TerraSAR-X multibeam spotlight data. IEEE Trans. Geosci. Remote Sens. 48, 971-977. https://doi.org/10.1109/TGRS.2009.2037315.

Rodríguez, E., Morris, C.S., Belz, J.E., 2006. A global assessment of the SRTM performance. Photogramm. Eng. Remote Sens. 72, 249-260. https://doi.org/10.14358/ PERS.72.3.249.

Salvini, R., Carmignani, L., Francioni, M., Casazza, P., 2015. Elevation modelling and palaeo-environmental interpretation in the Siwa area (Egypt): application of SAR interferometry and radargrammetry to COSMO-SkyMed imagery. CATENA 129, 46-62. https://doi.org/10.1016/j.catena.2015.02.017.

SARMAP, 2016. SARscape - Online Help.

Schubert, A., Small, D., Jehle, M., Meier, E., 2012. Accuracy after compensation for earthsystem effects 3301-3304.

Silveira, J.D.A., 1964. Morfologia do litoral. In: Brasil a Terra E O Homem. Companhia Editora Nacional, São Paulo, pp. 253-305.

Soergel, U., Michaelsen, E., Thiele, A., Cadario, E., Thoennessen, U., 2009. Stereo analysis of high-resolution SAR images for building height estimation in cases of orthogonal aspect directions. ISPRS J. Photogramm. Remote Sens. 64, 490-500. https://doi.org/ 10.1016/j.isprsjprs.2008.10.007.

Szabó, G., Singh, S.K., Szabó, S., 2015. Slope angle and aspect as influencing factors on the accuracy of the SRTM and the ASTER GDEM databases. Phys. Chem. Earth, Parts A/B/C 83-84, 137-145. https://doi.org/10.1016/j.pce.2015.06.003.

Tachikawa, T., Kaku, M., Iwasaki, A., Gesch, D., Oimoen, M., Zhang, Z., Danielson, J., Krieger, T., Curtis, B., Haase, J., Abrams, M., Crippen, R., Carabajal, C., 2011. ASTER Global Digital Elevation Model Version 2 - Summary of Validation Results. NASA L. Process. Distrib. Act. Arch. Cent. Jt. Japan-US ASTER Sci. Team 1-27.

Taylor, K.E., 2001. Summarizing multiple aspects of model performance in a single diagram. J. Geophys. Res. Atmos. 106, 7183-7192. https://doi.org/10.1029/ 2000JD900719.

Tessler, M.G., Goya, S.C., 2005. Processos Costeiros Condicionantes do Litoral Brasileiro. Rev. do Dep. Geogr. 17, 11-23.

Toutin, T., 2004. Review article: geometric processing of remote sensing images: models, algorithms and methods. Int. J. Remote Sens. 25, 1893-1924. https://doi.org/10. 1080/0143116031000101611.

Toutin, T., 2002. Impact of terrain slope and aspect on radargrammetric DEM accuracy. ISPRS J. Photogramm. Remote Sens. 57, 228-240. https://doi.org/10.1016/S09242716(02)00123-5.

Toutin, T., 2000. Evaluation of radargrammetric DEM from RADARSAT images in high relief areas. IEEE Trans. Geosci. Remote Sens. 38, 782-789. https://doi.org/10.1109/ 36.842007.

Toutin, T., Chenier, R., 2009. 3-D radargrammetric modeling of RADARSAT-2 ultrafine mode: preliminary results of the geometric calibration. IEEE Geosci. Remote Sens. Lett. 6, 611-615. https://doi.org/10.1109/LGRS.2009.2024391.

Toutin, T., Gray, L., 2000. State-of-the-art of elevation extraction from satellite SAR data. ISPRS J. Photogramm. Remote Sens.

Wang, Y., 2010. Remote Sensing of Coastal Environments, Taylor \& Francis Series in Remote Sensing Applications. CRC Press/Taylor \& Francis.

Wessel, B., Gruber, A., Huber, M., Breunig, M., Wagenbrenner, S., Wendleder, A., Roth, A., 2014. Validation of the absolute height accuracy of TanDEM-X DEM for moderate terrain. In: 2014 IEEE Geoscience and Remote Sensing Symposium. IEEE, pp. 3394-3397. https://doi.org/10.1109/IGARSS.2014.6947209.

Woodhouse, I.H., 2006. Introdution to Microwave Remote Sensing. CRC Press/Taylor \& Francis, New York.

Zamboni, A., Nicolodi, J.L., 2008. Atlas do Macrodiagnóstico da Zona Costeira e Marinha do Brasil [WWW Document]. Ministério do Meio Ambient. < http://www.mma.gov. $\mathrm{br} /$ component/k2/item/7562?Itemid $=866>$ (accessed 2.16.16).

Zeger, L.M., Avent, R., 2013. Terrain effect analysis for cross-track stereo SAR elevation estimation. IEEE Trans. Aerosp. Electron. Syst. 49, 2225-2234. https://doi.org/10. 1109/TAES.2013.6621812. 